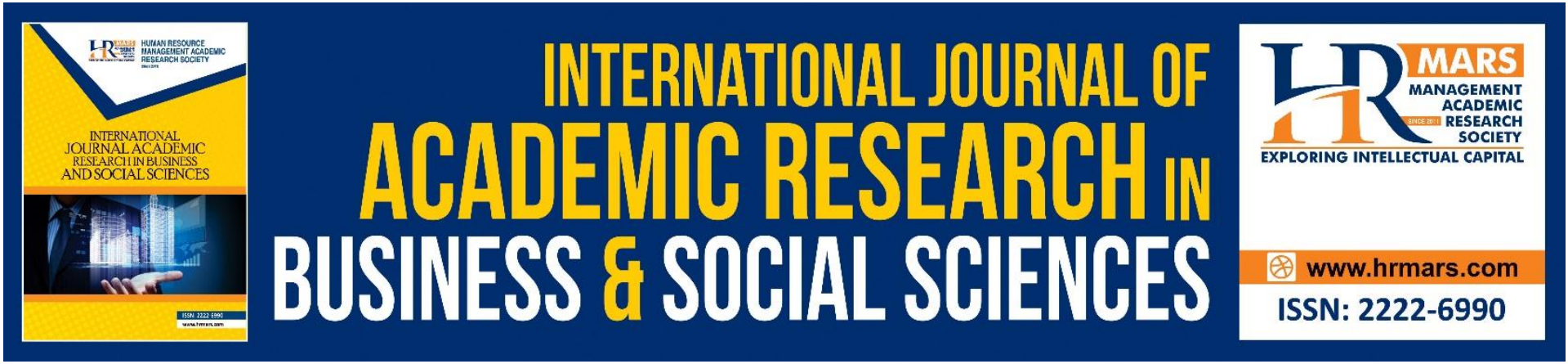

\title{
Does Financial Development Contribute to Fertility Decline in Developed and Developing Countries?
}

Asma' Rashidah Idris, Muzafar Shah Habibullah, Tismazammi Mustafa

To Link this Article: http://dx.doi.org/10.6007/IJARBSS/v11-i18/11429

DOI:10.6007/IJARBSS/v11-i18/11429

Received: 07 August 2021, Revised: 28 August 2021, Accepted: 23 September 2021

Published Online: 05 October 2021

In-Text Citation: (Idris et al., 2021)

To Cite this Article: Idris, A. R., Habibullah, M. S., \& Mustafa, T. (2021). Does Financial Development Contribute to Fertility Decline in Developed and Developing Countries? International Journal of Academic Research in Business and Social Sciences, 11(18), 71-105.

Copyright: (C) 2021 The Author(s)

Published by Human Resource Management Academic Research Society (www.hrmars.com)

This article is published under the Creative Commons Attribution (CC BY 4.0) license. Anyone may reproduce, distribute, translate and create derivative works of this article (for both commercial and non-commercial purposes), subject to full attribution to the original publication and authors. The full terms of this license may be seen

at: http://creativecommons.org/licences/by/4.0/legalcode

Special Issue Title: TiBECVII 2021, 2021, Pg. 71 - 105

Full Terms \& Conditions of access and use can be found at http://hrmars.com/index.php/pages/detail/publication-ethics 


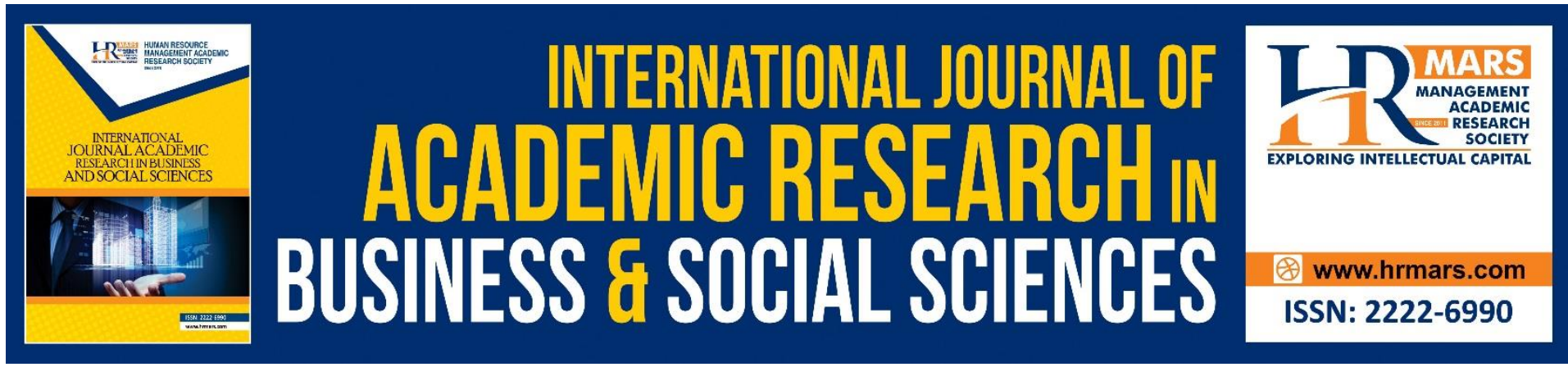

\title{
Does Financial Development Contribute to Fertility Decline in Developed and Developing Countries?
}

\author{
${ }^{1}$ Asma' Rashidah Idris, ${ }^{2}$ Muzafar Shah Habibullah, \\ ${ }^{3}$ Tismazammi Mustafa \\ ${ }^{1}$ Faculty of Business Management, Universiti Teknologi MARA Cawangan Negeri Sembilan, \\ Malaysia, ${ }^{2}$ Faculty of Economics and Management, Universiti Putra Malaysia, Malaysia, \\ ${ }^{3}$ Faculty of Business Management, Universiti Teknologi MARA Cawangan Kelantan, Malaysia \\ Email: asmar440@uitm.edu.my
}

\begin{abstract}
The "old-age security" hypotheses propose that financial market can affect individuals' decision to have less or more children. In previous literature, children are considered an asset and investment at low level of financial development that could bring returns and security during old age. Nevertheless, at higher level of financial development, individuals have more access to fund and opportunity for investment during old age and as a result the demand for children is less. Furthermore, increase in female labour participation rate in the economic sectors will also discourage them to have more children. The development of commercial bank and non-banking financial institutions (NBFIs) has broadened credit accessibility and investment opportunity to household over the last decades. Well-developed financial system facilitates firms to access to the credit market and enhanced production efficiency and promote increases in wages in the modern market. Household have choice to move from traditional market (low wages, high fertility rate) to work in modern sector (high wages, low fertility rate). The purpose of the study is to investigate the impact of financial development on fertility for selected developed and developing countries. We employ generalized method of moment (GMM) model using annual data from 2005 to 2011. Our results found that financial development and fertility has inverse relationship for both developed and developing countries.
\end{abstract}

Keywords: Fertility, Financial Development, Old-Age Security, Credit Accessibility, Investment Opportunity.

\section{Introduction}

Fertility behaviour and financial development have seen intense changes in recent decades, as both demonstrated distinctive patterns. Worldwide, financial development has upgraded the conceivable credit and intertemporal trade for households and firms; fertility has revealed an unmistakable descending pattern, which is alarming (Figure 1). The declining fertility rate is expected to be soon experienced by many nations, especially among developed nations (Adserà, 2004). Meanwhile, the growth in financial development (Figure 2) and well- 
developed financial system supports firm accessibilities to credit market and encourages production efficiency while contributing to salary rise in wages in the modern market. This often provides parents with the opportunity to work in the modern sectors (high wages, low fertility rate) instead of retaining traditional sector (low wages, high fertility rate) (Habibullah, Farzaneh and Haji Din, 2016; Varvarigos and Arsenis, 2015)

The development of the financial sector and financial deepening has however resulted in shadow banking becoming an important issue (FSB, 2016). Advancement in businesses and rising household debt due to a higher rate of lending activities provided by non-financial banking institutions has become a concern in several developed and developing countries (Gallin, 2013; Konno, Teramoto, and Mera, 2011). The issue of cost of raising children has been concerned is one of the main reason of rising household debt in many nations (Ahmad Khan, Abdullah, and Samsudin, 2016; Beecham, 2006; Kim, Engelhardt, Prskawetz, and Aassve, 2009; Werding, 2014). The Becker's idea that quality children (human capital) are investment goods (as perceived and demanded by parents) are subject to a large variety of parental "investments" in children (Becker, 1960a) such as monetary expenditure on food, clothing, shelter, health and medical care, child care to provide for a higher living standard of each child and support them in obtaining a better education. The children expenses certainly depend on level of socio-economics status, lifestyle and economic affluence of the parents (Hermeto and Caetano, 2009). Low income family (mostly in developing countries) certainly borrow to pay for those expenses due to high fertility rate (more children), meanwhile high income family with low fertility rate (mostly in developed countries) also borrow due to high cost of living standard (Werding, 2014). Household takes loans for smoothing their consumption with the expectation of an increase in future income. The life cycle model of Modigliani and Brumberg (1954) states household behaviour over a given period by smoothing the consumption through borrowing and saving. Raising household debt for current consumption is quite worrying which household spend more than monthly income received. Looking at the current trends, the household take loans to overcome the financial and economic difficulties (Anderloni, Bacchiocchi, \& Vandone, 2012). Instead of smoothing their consumption, they lose their savings which may lead to financial vulnerability (Abid and Mohd Shafiai, 2018). Although financial development and its determinants are often being discussed globally, there still exists significant element that is ambiguity and uncertainty in the empirical research of associated between financial development and economics of fertility. Or does fertility is really matter of well-developed financial system that is overlooked among researchers? The purpose of the study is to examine the effect of financial development on total fertility rate in both developed and developing countries for the period from 2005 to 2011. In the study, we highlight on the role of financial development as an important factor for declining fertility. 


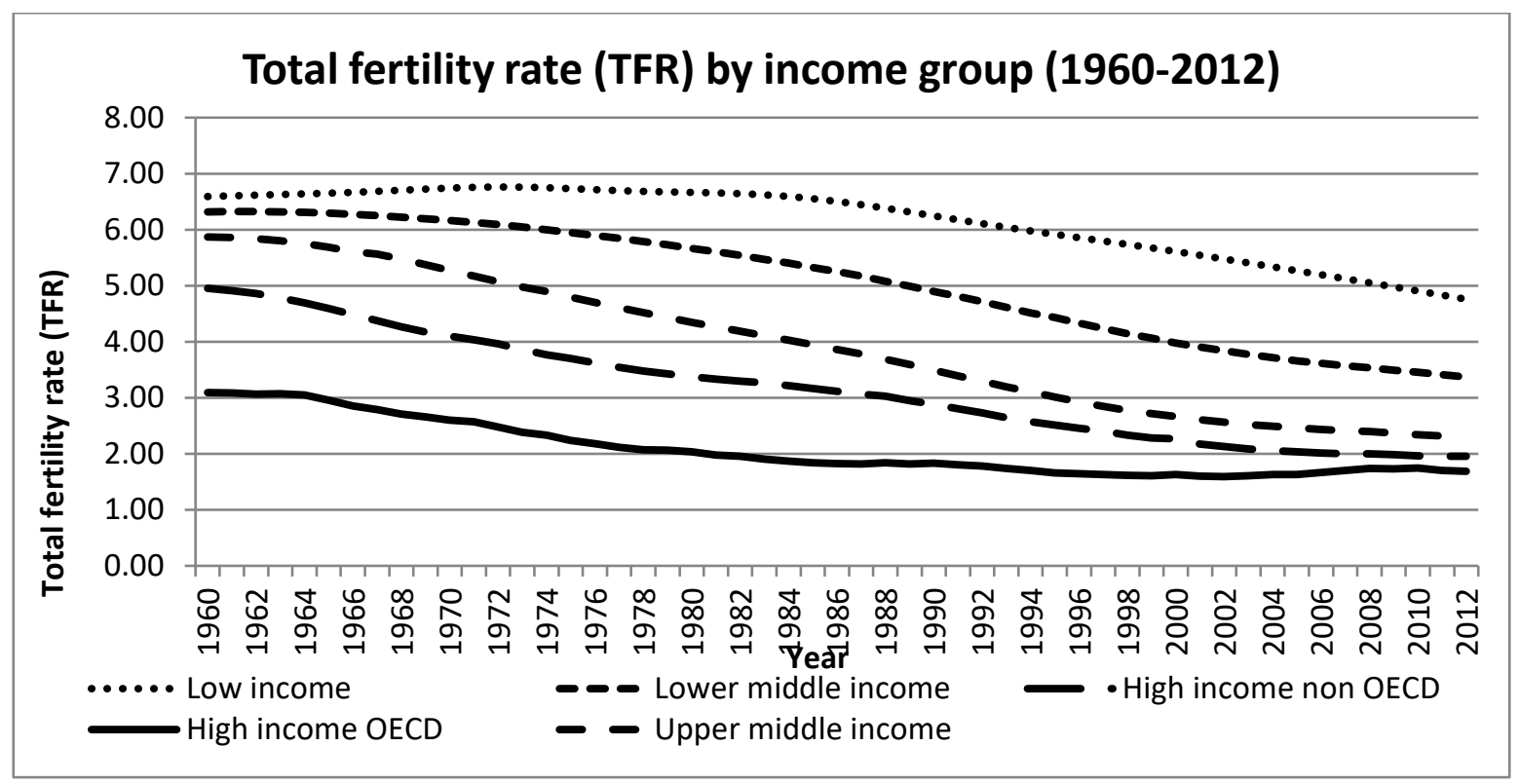

Figure 1: Total fertility rate (TFR) by income group (1960-2012)

Source: World Development Indicator (WDI), World Bank.

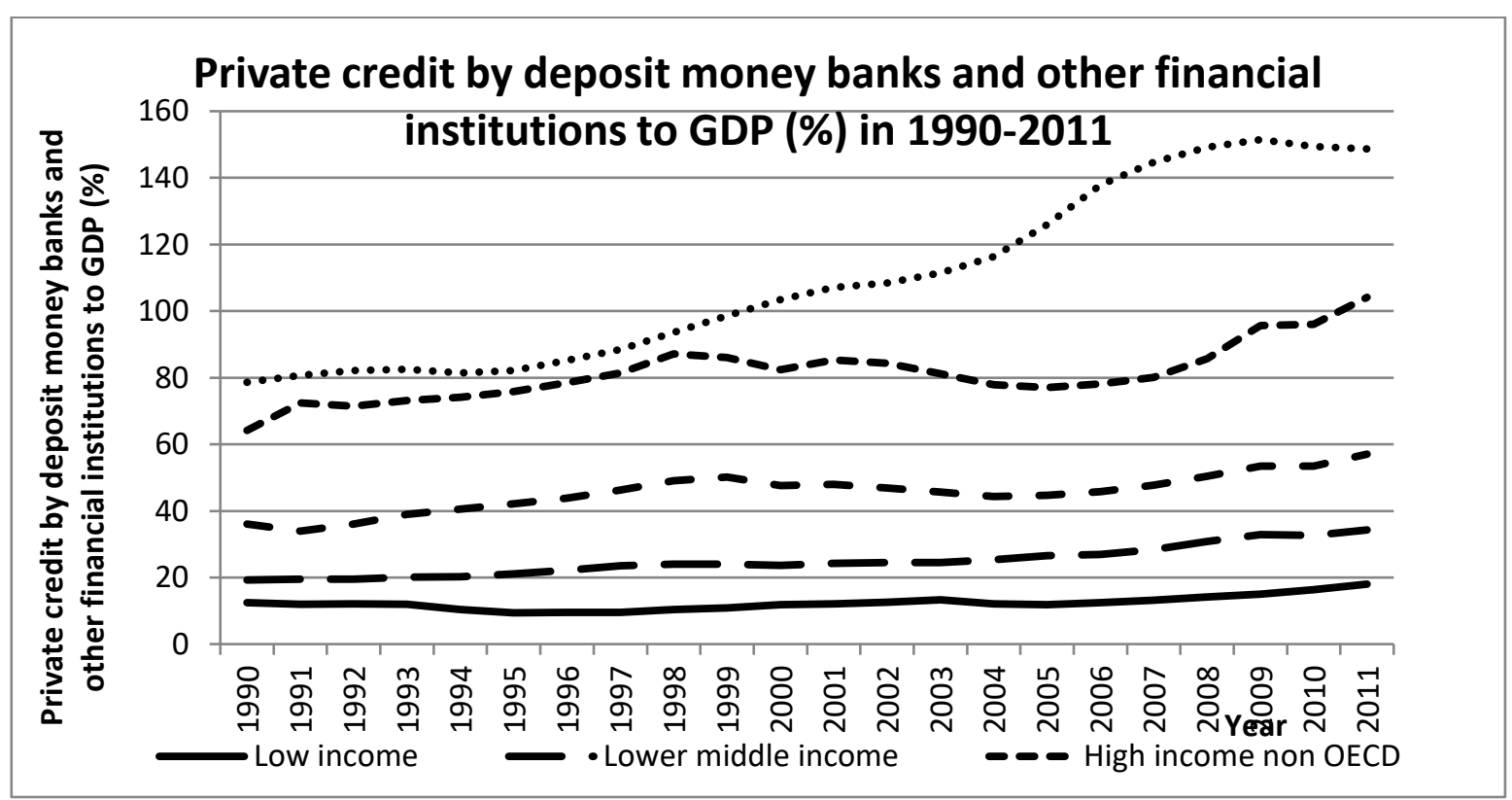

Figure 2: Private credit by deposit money bank and other financial institutions to GDP

(\%) in 1990-2011

Source: Global Financial Development Database, World Bank

(www.worldbank.org/financialdevelopment)

\section{Literature Review}

\section{Theories on Fertility}

Most theoretical work on the economics of fertility was developed from studies by Leibenstein (1957) and Becker (1960) in which the economic theory of consumer behaviour was applied to childbearing (Robinson and Horlacher, 1971). Leibenstein (1957) claims that children increase their families' lifetime wealth instead of being net consumers of family resources. During their youth, they are capable of working and are a source of income to their families. Fertility is seen as a financially profitable trade when the value of resources returned 
by the grown-up children exceeds the value of resources consumed during infants. While the microeconomic theory of fertility highlights the demand for children as the key to understanding fertility behaviour. It also treats the costs of controlling fertility. This conventional theory of consumer behaviour views the individual as trying to maximise satisfaction, given a range of goods, their prices, and individual tastes and income. In regards to fertility analysis, this theory views children as a special kind of good, and fertility is seen as a response to the consumer's demand for children relative to other goods (Easterlin, 1975).

In the last few years, derived primarily from an article by Becker (1965), the principal innovation in the present approach, which builds on prior work by Tabbarah (1971) is more explicit and formally treats the production of children, including the possibility of shifts in output, independent of demand conditions. Attention to the production side leads to greater recognition of such sociological concepts as natural fertility and of real world conditions to which the usual demand analysis may be inapplicable. Later, it is distinguished by use of the concept of a 'household production function' by Schultz (1973). Neher (1971) and Caldwell (1976) first proposed old-age security hypothesis around the time of industrial revolution where parents often viewed children as an instrument to secure old age support. Therefore, in the absence of capital markets, children serve as an asset that permits parents to transfer income to old age.

Another model economic choice of the family unit which uses dynamic macro-style frameworks known as Barro-Becker model has become dominant in investigating a range of issues and policies. One of the key decisions of a family is the fertility choice. Deciding on the number of children and the number of resources to invest in each of them has a long lasting impact on the economic outcomes of all family members. The influential work of Becker and Barro (1988) and Barro and Becker (1989) pioneered the use of dynamic altruistic models of fertility choice. The following are three controversial predictions of the model: (i) fertility is independent of family income; (ii) children are a net financial burden to society; and (iii) individual consumption is negatively associated to individual income.

\section{Fertility and Financial Development}

The association between fertility transition with financial development had also been discussed among economists recently (Cigno and Rosati, 1992; Filoso and Papagni, 2011; Lehr, 1999). Lehr (1999) suggested that financial intermediation can influence fertility and labour allocation decisions by raising market wages. An increase in income raises fertility and financial intermediations. On the other hand, the negative impact of financial intermediation on fertility would reveal an opposite story for income. Therefore, it may be true that income changes can cause fertility and financial intermediation, further suggesting that there is an independent causal role for financial intermediation in driving fertility movements. In other words, the emergence of or improvements to the financial intermediation sector will facilitate the movement of labour from the traditional to the modern sector, and this will contribute to the fertility decline, as experienced by many developing countries. Data were estimated by employing panel VAR using financial intermediation, fertility and industrial employment share of 87 countries, which the empirical evidence shows that the results are consistent with the theoretical predictions. 
Credit availabilities and opportunities for financial investment further influence fertility decisions. Cigno and Rosati (1992) determined the extent to which saving and fertility decisions were affected by the availability and attractiveness of market-based or stateprovided alternatives to the family as a source of old age support. The result showed that increase in fully funded social security coverage had a negative effect on fertility and a positive effect on saving. Moreover, greater access to the capital market adversely affected both fertility and saving. The estimated result was analysed from the Italian time series data between 1953 and 1984.

By employing co-integrating regression, Cigno and Rosati (1996) identified that financial development reduces fertility rates in Germany, Italy, UK and USA. The estimates are consistent with the hypothesis that, parents' self-interested determines saving and fertility in each country. The data also found that self-financing expansion of social security reduces fertility and rises household saving. Another convincing evidence on old-age hypothesis done by Basso et al. (2014) found that the presence of bank and developed local financial market are strongly associated with lower children-to-women ratios. This was observed using the data from 196 counties in the Northeastern United States (Connecticut, Delaware, Massachusetts, New Hampshire, New Jersey, New York, Pennsylvania, Rhode Island, and Vermont) in the 19th century.

Cigno and Rosati (1997) formulated alternative models of household saving behaviour which were tested using Japanese post-war time series data. The early rise and fall of the saving rate explained by the interaction of state, capital market and extended family as providers of oldage social security. This theory foresees saving rate is to be influenced positively by productivity growth and negatively by social security coverage and the dependency ratio (number of children and retirement age people per person of working age).

Meanwhile, Lehr (1999) proposed a theoretical framework that financial intermediation by raising wages can affect fertility and labour allocation decisions. The increase in wages encourages households to abandon traditional sector intensive methods of production and supply labour for modernised firms. The participation of households in the modern sector and labour allocation decision leads to lower fertility rate. The theory designates two predictions: first, the development of financial intermediaries within one country will lower fertility and increase future employment in modern sector, and secondly, the countries with higher level of financial intermediation will have lower fertility level and higher modern sector employment as compared to countries with lesser level of financial intermediaries.

Following, Basso et al. (2014) developed a simple theoretical framework that justifies the negative association between financial development and the number of children that parents decide to have. The theory explains that an exogenous increase in the probability of a bank being present near the household location, which acts as a proxy for financial development, will reduce the number of children that the parents decide to have.

Credit availability and financial investment opportunity influence fertility choices among parents. A study done by Filoso and Papagni (2015) suggest that households' greater demand for credit reduces fertility in poor countries while increasing fertility in high-income countries. Financial development affects adult behaviour in two different periods and ways; households 
become net borrowers during the first years of parenthood, and later, they become savers later on as their dependents leave home and approaching their retirement. The study using panel fixed effect model on 78 countries over the period 1995 to 2010.

Recently, Habibullah, Farzaneh, and Din (2016) support the findings by Filoso and Papagni (2015) which they found that fertility choices were positively influenced by financial development in high-income countries whereas, in low-income countries, financial development adversely affected fertility rate. The study employed the fixed effects and random effects models using annual data ranging from 1980-2010.

\section{Methodology}

The data set consists of a set of balanced panel data for 85 countries, comprising 42 developed countries and 43 developing countries covering the period of 2005 to 2011 . The data were collected from Global Financial Development Database (GFDD) published by the World Bank. The data of financial openness is taken from Chinn-Ito Openess Index Database. Data of human development index are obtained from United Nation Data. Governance indicators data are compiled from Worldwide Governance Indicators (WDI) published by the World Bank. Other regressors are extracted from World Development Indicator, published by the World Bank (Table 1). The lists of developed and developing countries are listed in Table 2 .

Table 1: Variables, measurement and sources

\begin{tabular}{|c|c|c|}
\hline Variables & Measurement & Sources \\
\hline Ltfr & $\begin{array}{l}\text { Total fertility rate (total birth rate per } \\
\text { women) }\end{array}$ & $\begin{array}{l}\text { World } \\
\text { Indictor (WDi), World } \\
\text { Bank }\end{array}$ \\
\hline Ldebt & Household debt to disposable income ratio & Eurostat \\
\hline Lfinsta & $\begin{array}{l}\text { Financial stability, Z-score of county's } \\
\text { commercial banks as proxy of financial } \\
\text { stability }\end{array}$ & $\begin{array}{lr}\text { Global } & \text { Financial } \\
\text { Development } & \text { Database, } \\
\text { World Bank } & \end{array}$ \\
\hline Iprivcred & $\begin{array}{l}\text { Private credit by deposit money banks and } \\
\text { other financial institutions to GDP (\%) }\end{array}$ & $\begin{array}{lr}\text { Global } & \text { Financial } \\
\text { Development } & \text { Database, } \\
\text { World Bank } & \end{array}$ \\
\hline Ldeposit & Deposit money banks' assets to GDP (\%) & $\begin{array}{lr}\text { Global } & \text { Financial } \\
\text { Development } & \text { Database, } \\
\text { World Bank } & \end{array}$ \\
\hline Lliqliab & Liquid liabilities to GDP (\%) & $\begin{array}{ll}\text { Global } & \text { Financial } \\
\text { Development } & \text { Database, } \\
\text { World Bank } & \end{array}$ \\
\hline Lfememp & $\begin{array}{l}\text { Female employment (\% of total labor } \\
\text { force) }\end{array}$ & $\begin{array}{l}\text { World } \quad \text { Development } \\
\text { Indictor (WDI), World } \\
\text { Bank }\end{array}$ \\
\hline Ltop & $\begin{array}{l}\text { Foreign trade (\% of GDP); ratio of export } \\
\text { plus imports of goods and non-factor } \\
\text { services to GDP }\end{array}$ & $\begin{array}{l}\text { World Development } \\
\text { Indictor (WDI), World } \\
\text { Bank }\end{array}$ \\
\hline Lhd & Human development index (HDI) & $\begin{array}{l}\text { United } \\
\text { Development }\end{array}$ \\
\hline
\end{tabular}


INTERNATIONAL JOURNAL OF ACADEMIC RESEARCH IN BUSINESS AND SOCIAL SCIENCES

Vol. 11, No. 18, TiBECVII 2021, 2021, E-ISSN: 2222-6990 @ 2021 HRMARS

\begin{tabular}{|c|c|c|}
\hline & & $\begin{array}{l}\text { Programme, United } \\
\text { Nations }\end{array}$ \\
\hline Lfinopen & Financial openness index & Chinn-Ito Index \\
\hline Lbocta & $\begin{array}{l}\text { Bank efficiency: bank overhead cost per } \\
\text { total assets }\end{array}$ & $\begin{array}{lr}\text { Global } & \text { Financial } \\
\text { Development } & \text { Database, } \\
\text { World Bank } & \\
\end{array}$ \\
\hline Lhp & House price index & OECD Factbook Statistics \\
\hline Lsav & $\begin{array}{l}\text { Saving rate; household saving relative to } \\
\text { disposable income }\end{array}$ & OECD Factbook Statistics \\
\hline Lint & $\begin{array}{l}\text { Short interest money market interest rate } \\
\text { (\%) }\end{array}$ & $\begin{array}{l}\text { World Development } \\
\text { Indictor (WDI), World } \\
\text { Bank }\end{array}$ \\
\hline Linf & $\begin{array}{l}\text { Inflation rate, consumer price (annual } \\
\text { percent change) }\end{array}$ & $\begin{array}{l}\text { World Development } \\
\text { Indictor (WDI), World } \\
\text { Bank }\end{array}$ \\
\hline Lwealth & $\begin{array}{l}\text { Household financial asset; currency and } \\
\text { deposit as a percentage of total financial } \\
\text { asset }\end{array}$ & OECD Factbook Statistics \\
\hline Lyouth & $\begin{array}{l}\text { Working ratio; population above } 15 \\
\text { relative to total population }\end{array}$ & $\begin{array}{l}\text { World } \quad \text { Development } \\
\text { Indictor (WDI), World } \\
\text { Bank }\end{array}$ \\
\hline Lod & $\begin{array}{l}\text { Old-age dependency ratio; population over } \\
65 \\
\text { relative to population between } 15-65 \text { years }\end{array}$ & $\begin{array}{lr}\text { World } & \text { Development } \\
\text { Indictor (WDI), World } \\
\text { Bank }\end{array}$ \\
\hline Ly & Real GDP per capita & $\begin{array}{l}\text { World } \\
\text { Indicator (WDI), World } \\
\text { Bank }\end{array}$ \\
\hline Lue & Unemployment rate (\%) & $\begin{array}{l}\text { World Development } \\
\text { Indicator (WDI), World } \\
\text { Bank }\end{array}$ \\
\hline $\begin{array}{l}\text { Lva, Ipsv, Ige, Irq, } \\
\text { Irl, Icc } \\
\text { (Governance) }\end{array}$ & $\begin{array}{l}\text { Set of governance indicators; voice and } \\
\text { accountability (VA), political stability and } \\
\text { absence of violence (PSV), government } \\
\text { effectiveness (GE), regulatory quality (RQ), } \\
\text { rule of law (RL) and control of corrupt (CC). }\end{array}$ & $\begin{array}{l}\text { World } \\
\text { Indicator } \\
\text { Bank }\end{array}$ \\
\hline
\end{tabular}


Table 2: List of countries included in the study (2005-2011)

Developed countries

Argentina

Australia

Austria

Bahrain

Belgium

Chile

Croatia

Cyprus

Czech Republic

Denmark

Finland

France

Germany

Greece

Hong Kong SAR, China

Hungary

Iceland

Ireland

Italy

Japan

Korea, Rep.

Kuwait

Latvia

Lithuania

Malta

Netherlands

Oman

Poland

Portugal

Qatar

Saudi Arabia

Singapore

Slovak Republic

Slovenia

Spain

Sweden

Switzerland

Trinidad and Tobaco

United Arab Emirates

United Kingdom

United States

Uruguay
Developing countries

Armenia

Bangladesh

Botswana

Brazil

Bulgaria

China

Colombia

Costa Rica

Ecuador

Egypt, Arab Rep

El Salvador

Georgia

Guyana

Indonesia

Jamaica

Jordan

Kazakhstan

Kenya

Kyrgyz Republic

Lebanon

Malawi

Malaysia

Mauritius

Mexico

Mongolia

Morocco

Namibia

Nepal

Nigeria

Pakistan

Panama

Peru

Philippines

Russian Federation

South Africa

Sri Lanka

Thailand

Tunisia

Turkey

Uganda

Ukraine

Vietnam

Zambia 
This study acknowledged the existence of relation between the chosen indicators of the financial sector development, namely private credit, deposit money and liquid liabilities with the dependent variable (y) fertility. In developed countries, there is well-organised financial market and banking sectors and improved financial instruments/services, as compared to developing countries, which is poorly or least developed financial market (Liu and Hsu, 2006), thereby, it might have different impact of financial development on number of children preferred by parents. Therefore, study is analysed based on different sample of developed and developing countries.

The model function for fertility can be illustrated as in the following: $t f r=\{f i n d e v, y$, top, fememp, hd, bocta, finopen, govern $\}$

Where the fertility model can be specified as the following equation:

$\operatorname{InTFR}{ }_{i t}=\alpha_{0}+\beta_{1} \operatorname{lnTFR} R_{i t-1}+\beta_{2} \operatorname{lnFINDEV} V_{i j t}+\beta_{3} \ln Y_{i t}+\beta_{4} \operatorname{lnTOP} P_{i t}+\beta_{5} \operatorname{lnFEMEMPit}+\beta_{6} \ln \operatorname{lD}_{i t}+$ $\beta_{7} \ln B O C T A_{i t}+\beta_{8} \ln F I N O P E N_{i t}+\beta_{9} \operatorname{lnGOVERN}{ }_{i j t}+v_{i}+\mu_{i t}$

(Equation 1)

where,

FINDEV $_{i j}=$ PRIVCRED, DEPOSIT, LIQLIAB

GOVERN $N_{i j}=C C, G E, P S V, R Q, R L, V A$

where TFR is total fertility rate, FINDEV is a set of financial sector development indicators, $v$ is a country-specific, and $\mu$ is a transitory error term that varies across countries. The subscript $i$ is for countries while $t$ is for time periods. The PRIVCRED is private credit, DEPOSIT is deposit money, LIQLIAB is liquid liabilities, $Y$ is real GDP per capita, TOP is trade openness, FEMEMP is female employment, HD is human development, BOCTA is banking efficiency, FINOPEN is financial openness, and last but not least, GOVERN is set of governance indicators; voice and accountability (VA), political stability and absence of violence (PSV), government effectiveness (GE), regulatory quality (RQ), the rule of law (RL) and control of corrupt (CC). All variables are in natural logarithms.

This study applied dynamic panel data analysis which we include lagged one period of the dependent variable in equation of dependent variable; FERTILITY. To deal with dynamic panel data is to apply first-differenced General Method of Moment (GMM) estimators by taking the levels of the series lagged two periods or more as instrumental variables. It can be done when the number of time series observations is large, if not the first-differenced GMM will be estimated poorly that caused by lagged levels of variables being weak instruments for subsequent first-differences (Bond, Hoeffler, \& Temple, 2001). The weakness of firstdifferences is lightened by the system GMM estimator suggested by Arellano \& Bover (1995) and Blundell \& Bond (1998). The general idea of system GMM is to combine both equations in first differences, taking the lagged level variables as instruments, with equations in levels with lagged first differences as instruments.

Moreover, two-step system GMM procedure effectively controls for autocorrelation and heteroskedasticity, which provides consistent coefficient estimates and performs more reliable Arellano and Bond tests for serial correlation (Blundell \& Bond, 1998). If the null 
hypothesis of no serial correlation of $A R(2)$ model failed to reject, it can be an evidence of supporting the validity of instrument used. In addition, specification test are conducted using Hansen test to check of the validity of these instruments variables. Based on the Hansen test, the null hypothesis of no correlation between instruments and errors, and failure to reject the null can be regarded as evidence in favour of using valid instruments. Taking into consideration of all the statistical characteristics, limitations and restrictions and looking for suitability, two steps Dynamic System GMM was preferred for our analysis.

\section{Justification, Variable Description and Expected Sign}

Private Credit (Lprivcred): Private credit by deposit money banks and other financial institutions to GDP measures the activity of financial intermediaries. It associates strongly with income level and long-term economic growth. In addition, it measures financial depth of financial sector relative to the economy. It is the size of the banks, other financial institutions and financial markets taken together and compared to a measure of economic output. This variable is selected because it take into consideration of shadow bank system which measure non-bank financial institutions (Other financial institutions) (Martin Cihak, Demirguc-Kunt, Feyen, and Levine, 2012). It is also closely related to poverty reduction and promoting economic growth (Demirgüç-kunt and Levine, 2008). The high value of private credit indicates a flourishing market for credit in general and also for households. According to Filoso and Papagni (2015) credit availability in LDCs reduces fertility rate. This negative income effect characterises children as an inferior good in poor countries. Meanwhile, the positive sign of the variable on fertility for high income economies suggests the role of children as a necessity that ensures their parents' old age consumption.

Deposit Money (Ldeposit): Deposit money banks' asset to GDP (\%) is evidence of the importance of the financial services performed by financial sectors, relative to the size of economy. The expected sign is negative. Countries with high deposit money will have high proportion of credit allocated in banking sector. Higher value denote that larger fraction of liquidity can be used by family to borrow in future. This variable influences fertility rate, depending on income level. If the family borrowing constraint is weak, they are not able to borrow although there is larger credit availability in the country, therefore, reducing fertility decision (Filoso and Papagni, 2011). Thus, the expected sign can be either negative or positive depending on income level.

Liquid Liability (Lliqliab): Liquid liability measure financial depth and absolute size of an economy based on liabilities, which is the broadest available indicator of financial intermediation. Liquid liability may affect fertility decision of parents either positively or negatively. The availability of alternative financial tool reduces the incentives of households to have large offspring (Zakari et al., 2016).

Real GDP per capita (Ly): The association between economic well-being and fertility is often debated extensively among researchers. Income is a significant determinant which influences parents to choose the desired quantity of the children. The birth rate has a negative effect on income. Countries with high income, improved health and high employment rate is synonym to a low number of children per family (Bloom et al., 2010; Hafner and Mayer-Foulkes, 2013; Liu and $\mathrm{Hu}, 2013)$. In contrast, Habibullah et a (2016) found that high-income countries contribute to high fertility rate. 
Trade openness (Ltop): Trade openness refers to the sum of exports and imports divided by GDP. Trade openness benefits the countries in a way that it allows more inflow and outflow of goods and services with many incentives and reduction of tariff barriers. Countries which are more open to trade liberalisation have chances for increased fertility (Hafner \& MayerFoulkes, 2013). This is due to positive income growth brought by reduction in short-run adjustment cost due to tariff cut and the influence of openness on commodity price level and consumption. Contrastingly, Galor and Mountford (2008) stated that international trade decreases in both developed and developing countries. As the gains from trade have been allocated to investment on education and population growth respectively, thus, the expected sign is either negative or positive.

Female Employment (Lfememp): Female employment represents women's participation in the labour market where they represent active involvement in economic activity and society. More women participate in the labour market is because of increased education level. Female employment has improved social status and women empowerment in society, allowing them to have more power in decision making, hence, enabling them to decide the number of children they prefer. The contributions of female benefits not only to their family but also increase economic growth. Their involvement have been observed in many areas of working for instance; agricultural, industries, manufacturing, banking sectors and other services. Therefore, female labour is considered as important determinant of reducing fertility rate (Bloom et al., 2009). Other studies share the same finding are Eltigani (2005) and Narayan (2006). The expected sign of female labour is negative.

Human development (Lhd): Human development index is used as proxy of human development which concerning to three components of human development index (HDI); wealth, health and education. The study shed light of relationship between fertility and human development because this variable is one of the significant determinants of declining fertility in most countries in the world especially in developed countries (Hafner \& MayerFoulkes, 2013; Varvarigos \& Arsenis, 2015; Wang \& Sun, 2016). The prior expectation based on demographic transition theory between human development and fertility is negative. In the study, it reveals negative association between human development and fertility in 188 countries in the world; Africa, America, Asia, the Pacific and Europe (Almasi-Hashiani, Sepidarkish, Vesali, \& Omani-Samani, 2016) and negative long-run relationship for subsample of developing countries(Hafner and Mayer-Foulkes, 2013). In United States, according to multivariate results, the negative relationship between human development and fertility exists in suburbans and rural counties as well as United States as a whole. However, the result is inconclusive for the urban counties (Ryabov, 2015).

Banking efficiency (Lbocta): Banks overhead costs as share of its total assets is employs as measure of efficiency which commercial banks perform the functions of financial intermediaries to channel funds from savers to investors. Banks raise funds from people looking to deposit money and lend out to individual who need it. This variable is significant to the model since we can see to what extend the banking efficiency can facilitate parents, in terms of borrowing constraint and investment which could affect number of children the parents decide to have. Efficiency of banking sectors providing services and financial instrument is one of the factors contributing the number of children parents prefer to have 
(Filoso and Papagni, 2015). In addition, the increasing role of women in the banking sector is significant as they actively participated in top positions of banks in contributing to banking efficiency (Adams and Harte, 1998; Chandani, Mehta, and Neeraja, 2014), thereby they are focusing on their tasks in the workplace while not prefer to have more children. The expected sign is negative.

Financial openness (Lfinopen): Financial openness is often associated with higher rate of economic growth and financial development. Financial openness in the stock market and banking sector development, and changes in the quality of institutions are among the reasons for financial liberalisation. Financially developed countries or those with high-quality institutions experience larger productivity growth responses. stock market and banking sector development, and to changes in the quality of institutions (Harvey, 2009). Financial liberalisation is also highly related to consumption and investment booms, and subsequent appreciation of exchange rates. Countries with higher growth rate often face reducing fertility rate. The expected sign is negative.

Governance (Lcc, Lge, Lpsv, Lrq, Lrl, Lva): The establishment of policies and continuous monitoring of proper implementation by the members of the governing body of organisation is important. Good governance contributes to development of the country. The inclusion of governance allows understanding the importance of governance to the fertility decisions. Governance consists of six components which include control of corruption (cc), government effectiveness (ge), political stability and absence of violence/terrorism (psv), regulatory quality (rq), the rule of law ( $\mathrm{rl}$ ), and voice and accountability (va). Wang and Sun (2016) suggested that freedom of oppression empower people with constitutional rights to choose their leaders and determine how much say they could have on government policies. In some extreme cases, it may determine how many children a couple could have or choose to have. Worsening political freedom employs downward pressure on fertility rates. Varvarigos \& Arsenis (2015) suggested that the negative relationship between fertility and economic development may also be affected by differences in the magnitude of bureaucratic corruption. More power on control of corruption decrease the misconduct and mishandling of the public officers, thus, increasing funds and income for the nations. The expected sign is positive.

\section{Results and Discussion}

Tables 3, 4, 5, 6 and 7, suggest a negative and statistically significant relationship for all financial development variables (Lprivcred, Ldeposit, Lliqliab) for both developed and developing countries. It indicated that empirical results supported the hypothesis that countries with higher access to financial development tend to experience lower fertility rate. In other words, the improved and organised financial system in developed countries influenced parents to have fewer children. These findings seems to mirror the findings by Cigno and Rosati (1992) who claimed that, increase in social security coverage and wider access to the capital market has negative effect on fertility. Lehr (1999) also found a negative relationship between financial development and the number of children per woman. It was observed that improvement in the financial intermediation sector facilitated the movement of labour from traditional to the modern sector, hence, contributing to the decline in fertility rate. Basso et al. (2014) mentioned that the presence of a bank and the degree of financial development are strongly associated with lower children-to-women ratios across North- 
eastern U.S, counties in the $19^{\text {th }}$ century. However, according to Filoso and Papagni (2011), higher credit reduced fertility in poor countries only. According to old-age hypothesis first proposed by Neher (1971) households use children as financial instruments to transfer their income during old age, when financial market is weak. However, the development of capital market reduces the demand for children for old age support, as developed capital market allow parents to borrow resources from financial institutions.

The positive effect of real GDP per capita on fertility for developed countries consistent with the recent study done by Habibullah et al (2016); suggesting that high-income countries lead to higher fertility rate. This indicates that wealthy societies can afford the high cost of childrearing for more number of children as well as invest in the quality of the children as their income level are high enough. However, as for developing countries, the result for real GDP per capita was negatively related to fertility. The result indicated that an increase in real GDP per capita for developing countries would reduce the number of birth per women (Tables 4, 6 and 8). It suggested that one major characterization of economic development is the developed lifestyle defined as high income, improved health and rising labour force to population is synonym with low fertility (Becker et al., 1990; Bloom et al., 2010; Hafner and Mayer-Foulkes, 2013; Liu and Hu, 2013).

Tables 3, 5 and 7 show the estimated coefficient of trade openness for developed countries in which a negative impact was observed on fertility. The result indicated that the expansion of trade openness would reduce the number of children per woman. However, in Tables 4, 6 and 8 , trade openness for developing countries has positive effect on fertility. The result implies that an increase in trade openness induces the number of birth per woman. The finding was similar to the previous study by Galor and Mountford (2008) which mentioned that cross-country regression analysis supports the hypothesis that international trade generates opposing effects on fertility rates and education in both developed and less developed economies. This demonstrates that international trade has a positive effect on fertility and a negative effect on human capital formation in non-OECD economies, whereas in OECD economies, trade triggers a decline in fertility and an increase in human capital accumulation.

Subsequently, Tables 3, 4, 5, 6, 7 and 8 also shows that the coefficient estimates for female labour force participation are negative and statistically significant on fertility in both developed and developing countries. The result suggests that female employment decreased the number of children per woman. Among the reasons for the decreasing fertility was the high-level of education achievement, increasing opportunities and changing nature of women in the workplace (Eltigani, 2005; Narayan, 2006). Such situations encourage them to delay marriage and postponing of having children. Currently, married female workers are spending more time in workplace rather than at home taking care of their children. This would be a reason for women to be reluctant to have many children.

In case of human development, the estimated of the coefficients showed a significant and negative relationship with fertility rate for developing countries but insignificant for developed countries. This indicates that high level of human development contributes to the decreasing number of birth per women. The result was supported by the study done by Hafner and Mayer-Foulkes (2013). Meanwhile, the estimated coefficient of banks' efficiency 
(Lbocta) for both developed and developing countries clearly showed a negative relationship with fertility due to banking efficiency. The results implied that an increase in banking efficiency would reduce fertility rate. The relationship between financial openness (Lfinopen) and fertility was also negative and statistically significant for both developed and developing countries, whereby, an increase in financial openness reduced the number of children per woman.

Next, the finding suggests a positive relationship between good governance and fertility for developed countries. It indicates that fertility level is would be higher when good governance is enforced in developed countries. The coefficients estimates showed that government effectiveness (Lge), regulatory quality (Lrq), rule of law (Lrl), control of corrupt (LCC) were significant and had a positive impact to fertility rate. Meanwhile, political stability and absence of violence/terrorism (Lpsv) had a significant and negative affect on the number of children per woman. The result indicated that a nation with an effective steady-state of the government system determined how many children a couple could have or choose to have in some extreme cases. The result was consistent with the previous finding by Wang and Sun (2016), which suggested that freedom of oppression empowers people with constitutional rights to choose their leaders and determine how much say they could have on government policies. Good governance enhanced quality of public services and its policy formulation and implementation; and the credibility of the government's commitment to such policies contributes to the increase in fertility rates. In other words, bad governance places downward pressure on fertility rates (Varvarigos \& Arsenis, 2015).

Meanwhile, for developing countries, the result reveals that good governance has negative effect on fertility. In other words, good governance can reduce fertility level. The coefficients estimates showed that government effectiveness (Lge), regulatory quality (Lrq), rule of law (Lrl), control of corrupt (LCC) and voice and accountability (Lva) were significant and had a negative impact to fertility rate. Only political stability and absence of violence/terrorism (Lpsv) had a significant and positive effect on the number of children per woman. As citizens become more educated, their expectations of government effectiveness and performance rise. If citizens' expectations rise faster than the actual performance of governments, trust (Kampen, De Walle, and Bouckaert, 2006) and satisfaction could decline (Huang, Chen, Liu, and Zhou, 2017). In fact, job satisfaction, commitment to achieve organization missions and career success are associated with humanistic management (Daley, 1986) and happiness index (Rego, Ribeiro, Pina e Cunha, and Jesuino, 2011). With less job satisfaction, commitment and responsibility to organization, it reduces happiness index (Lee et al., 2018) and fertility level as well. 
INTERNATIONAL JOURNAL OF ACADEMIC RESEARCH IN BUSINESS AND SOCIAL SCIENCES

Vol. 11, No. 18, TiBECVII 2021, 2021, E-ISSN: 2222-6990 ๔ 2021 HRMARS

Table 3: The effect of financial depth (private credit) on fertility (DEVELOPED)

\begin{tabular}{|c|c|c|c|c|c|c|c|c|c|c|c|}
\hline \multirow[t]{2}{*}{ Dependent Variable } & \multicolumn{11}{|c|}{ Fertility } \\
\hline & Model 1 & Model 2 & Model 3 & Model 4 & Model 5 & Model 6 & Model 7 & Model 8 & Model 9 & Model 10 & Model 11 \\
\hline \multirow[t]{3}{*}{ L.Itfr } & $\begin{array}{c}0.930 * * * \\
(163.58)\end{array}$ & $\begin{array}{c}0.923 * * * \\
(152.76)\end{array}$ & $\begin{array}{c}0.882 * * * \\
(120.45)\end{array}$ & $\begin{array}{c}0.881 * * * \\
(149.74)\end{array}$ & $\begin{array}{c}0.875^{* * *} \\
(143.71)\end{array}$ & $\begin{array}{c}0.859 * * * \\
(113.97)\end{array}$ & $\begin{array}{c}0.876 * * * \\
(115.19)\end{array}$ & $\begin{array}{c}0.875^{* * *} \\
(142.30)\end{array}$ & $\begin{array}{c}0.862 * * * \\
(87.11)\end{array}$ & $\begin{array}{c}0.859 * * * \\
(100.06)\end{array}$ & $\begin{array}{c}0.876 * * * \\
(145.78)\end{array}$ \\
\hline & - & - & - & - & - & & - & - & - & - & - \\
\hline & $0.00634 * *$ & $0.0145 * *$ & $0.0215 * *$ & $0.0211 * *$ & $0.0210 * *$ & - & $0.0237 * *$ & $0.0208 * *$ & $0.0318^{* *}$ & $0.0297 * *$ & $0.0212 * *$ \\
\hline \multirow[t]{3}{*}{ Lprivcred } & $*$ & $*$ & $*$ & $*$ & $*$ & $0.0236 * * *$ & $*$ & $*$ & $*$ & $*$ & $*$ \\
\hline & $(-4.02)$ & $(-5.77)$ & $(-12.19)$ & $(-8.12)$ & $(-8.56)$ & $(-11.01)$ & $(-10.14)$ & $(-8.11)$ & $(-7.33)$ & $(-8.98)$ & $(-9.14)$ \\
\hline & & $0.0128 * *$ & $0.0255^{* *}$ & $0.0202 * *$ & $0.0212 * *$ & & & $0.0212 * *$ & $0.0241 * *$ & & $0.0236 * *$ \\
\hline \multirow[t]{4}{*}{ Ly } & & $*$ & $*$ & * & * & 0.00748 & 0.0135 & $*$ & $*$ & 0.0151 & $*$ \\
\hline & & (3.92) & (7.84) & (4.87) & $(4.70)$ & (1.01) & $(2.60)$ & (4.67) & (5.07) & $(2.67)$ & $(4.43)$ \\
\hline & & & - & - & - & & - & - & - & - & - \\
\hline & & & $0.0124 * *$ & $0.0146 * *$ & $0.0147 * *$ & - & $0.0172 * *$ & $0.0141 * *$ & $0.0217^{* *}$ & $0.0194 * *$ & $0.0138 * *$ \\
\hline \multirow[t]{4}{*}{ Ltop } & & & $*$ & $*$ & $*$ & $0.0186 * * *$ & $*$ & $*$ & $*$ & $*$ & $*$ \\
\hline & & & $(-4.91)$ & $(-5.89)$ & $(-5.21)$ & $(-5.21)$ & $(-5.59)$ & $(-4.13)$ & $(-5.95)$ & $(-5.62)$ & $(-4.80)$ \\
\hline & & & & & & & - & & - & - & \\
\hline & & & - & - & - & - & $0.0584 * *$ & & $0.0509 * *$ & $0.0499 * *$ & - \\
\hline Lfememp & & & $\begin{array}{c}0.0280 * * \\
(-3.27)\end{array}$ & $\begin{array}{c}0.0290 * * \\
(-3.07)\end{array}$ & $\begin{array}{c}0.0353 * * \\
(-3.34)\end{array}$ & $\begin{array}{c}0.0571 * * * \\
(-4.77)\end{array}$ & $\begin{array}{c}* \\
(-3.64)\end{array}$ & $\begin{array}{c}-0.0322 \\
(-2.08)\end{array}$ & $\begin{array}{c}* \\
(-4.25)\end{array}$ & $\begin{array}{c}* \\
(-4.37)\end{array}$ & $\begin{array}{c}0.0538 * * \\
(-2.85)\end{array}$ \\
\hline \multirow[t]{3}{*}{ Lhd } & & & $\begin{array}{c}-0.00119 \\
(-0.25)\end{array}$ & $\begin{array}{c}-0.00544 \\
(-0.79)\end{array}$ & $\begin{array}{c}-0.00918 \\
(-1.12)\end{array}$ & $\begin{array}{c}-0.00946 \\
(-1.33)\end{array}$ & $\begin{array}{c}-0.0139 \\
(-1.62)\end{array}$ & $\begin{array}{c}-0.00846 \\
(-0.99)\end{array}$ & $\begin{array}{c}-0.0137 \\
(-1.64)\end{array}$ & $\begin{array}{c}-0.0120 \\
(-1.74)\end{array}$ & $\begin{array}{c}-0.0123 \\
(-1.38)\end{array}$ \\
\hline & & & & & - & - & & - & - & - & - \\
\hline & & & & & $0.00641^{*}$ & $0.00867^{* *}$ & & $0.00653^{*}$ & $0.00644^{*}$ & $0.00645^{*}$ & $0.00655^{*}$ \\
\hline \multirow[t]{4}{*}{ Lbocta } & & & & -0.00395 & $*$ & $*$ & -0.00623 & $*$ & $*$ & $*$ & $*$ \\
\hline & & & & $(-2.07)$ & $(-2.93)$ & $(-3.62)$ & $(-2.60)$ & $(-2.90)$ & $(-2.83)$ & $(-2.73)$ & $(-3.01)$ \\
\hline & & & & & & & - & & - & - & \\
\hline & & & & & & - & $0.0134 * *$ & & $0.0241 * *$ & $0.0176 * *$ & - \\
\hline \multirow[t]{2}{*}{ Lfinopen } & & & & & -0.00826 & $0.0124 * * *$ & $*$ & -0.00834 & $*$ & $*$ & $0.0107 * *$ \\
\hline & & & & & $(-2.63)$ & $(-4.52)$ & $(-3.67)$ & $(-2.62)$ & $(-3.64)$ & $(-3.87)$ & $(-3.21)$ \\
\hline Lcc & & & & & & $\begin{array}{c}0.0388^{* *} \\
(2.72)\end{array}$ & & & & & \\
\hline
\end{tabular}


INTERNATIONAL JOURNAL OF ACADEMIC RESEARCH IN BUSINESS AND SOCIAL SCIENCES

Vol. 11, No. 18, TiBECVII 2021, 2021, E-ISSN: 2222-6990 @ 2021 HRMARS

\begin{tabular}{|c|c|c|c|c|c|c|c|c|c|c|c|}
\hline Lge & & & & & & & $\begin{array}{l}0.0458 \\
(2.43)\end{array}$ & & & & \\
\hline Lpsv & & & & & & & & $\begin{array}{c}-0.00688 \\
(-0.30)\end{array}$ & & & \\
\hline Lrq & & & & & & & & & $\begin{array}{c}0.0534^{* *} \\
(3.50)\end{array}$ & & \\
\hline Lrl & & & & & & & & & & $\begin{array}{c}0.0496 * * \\
(3.05)\end{array}$ & \\
\hline Lva & & & & & & & & & & & $\begin{array}{l}0.0116 \\
(1.03)\end{array}$ \\
\hline _cons & $\begin{array}{c}0.0673 * * * \\
(7.66)\end{array}$ & $\begin{array}{c}-0.0236 \\
(-0.94)\end{array}$ & $\begin{array}{c}0.0674 \\
(1.86)\end{array}$ & $\begin{array}{c}0.134^{* * *} \\
(4.07)\end{array}$ & $\begin{array}{c}0.165^{* * *} \\
(4.32)\end{array}$ & $\begin{array}{c}0.396 * * * \\
(5.08)\end{array}$ & $\begin{array}{c}0.314^{* * *} \\
(4.79)\end{array}$ & $\begin{array}{c}0.158^{* * *} \\
(3.59)\end{array}$ & $\begin{array}{c}0.244^{* * *} \\
(6.42)\end{array}$ & $\begin{array}{c}0.311^{* * *} \\
(6.04)\end{array}$ & $\begin{array}{c}0.202^{* * *} \\
(4.64)\end{array}$ \\
\hline Observation & 252 & 252 & 252 & 252 & 252 & 252 & 252 & 252 & 252 & 252 & 252 \\
\hline No of Countries & 42 & 42 & 42 & 42 & 42 & 42 & 42 & 42 & 42 & 42 & 42 \\
\hline$A R(1)$ & 0.00324 & 0.00308 & 0.00239 & 0.00285 & 0.00322 & 0.00304 & 0.00304 & 0.00319 & 0.00256 & 0.00286 & 0.00324 \\
\hline $\operatorname{AR}(2)$ & 0.764 & 0.767 & 0.775 & 0.761 & 0.766 & 0.743 & 0.768 & 0.772 & 0.806 & 0.782 & 0.767 \\
\hline $\begin{array}{l}\text { Chi2 - Sargan test } p \text { - } \\
\text { value } \\
\text { Chi2 - Hansen test }\end{array}$ & $0.000 * * *$ & $0.000 * * *$ & $0.000^{* * *}$ & $0.000 * * *$ & $0.000 * * *$ & $0.000 * * *$ & $0.000^{* * *}$ & $0.000 * * *$ & $0.000 * * *$ & $0.000 * * *$ & $0.000 * * *$ \\
\hline$p$-value & 0.190 & 0.285 & 0.163 & 0.212 & 0.210 & 0.210 & 0.195 & 0.177 & 0.161 & 0.177 & 0.164 \\
\hline
\end{tabular}

Dependent variable: fertility (Ltfr), two-step system GMM. Figures in parenthesis are t-statistics. Asterisk (***) and $\left({ }^{* *}\right)$ denote statistically significant at the $1 \%$ and $5 \%$ level, respectively 
INTERNATIONAL JOURNAL OF ACADEMIC RESEARCH IN BUSINESS AND SOCIAL SCIENCES Vol. 11, No. 18, TiBECVII 2021, 2021, E-ISSN: 2222-6990 ๔ 2021 HRMARS

Table 4: The effect of financial depth (private credit) on fertility (DEVELOPING)

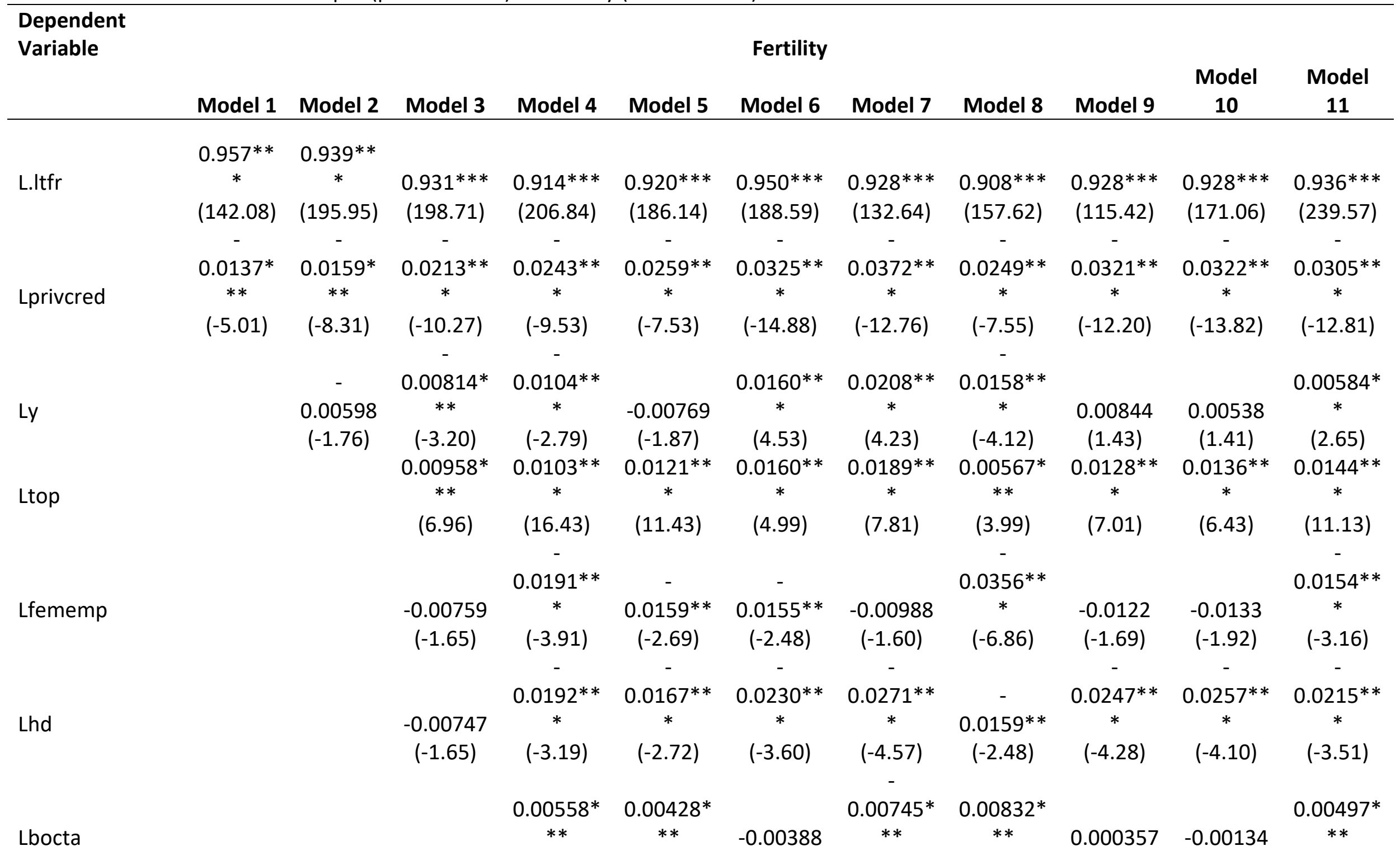


INTERNATIONAL JOURNAL OF ACADEMIC RESEARCH IN BUSINESS AND SOCIAL SCIENCES Vol. 11, No. 18, TiBECVII 2021, 2021, E-ISSN: 2222-6990 @ 2021 HRMARS

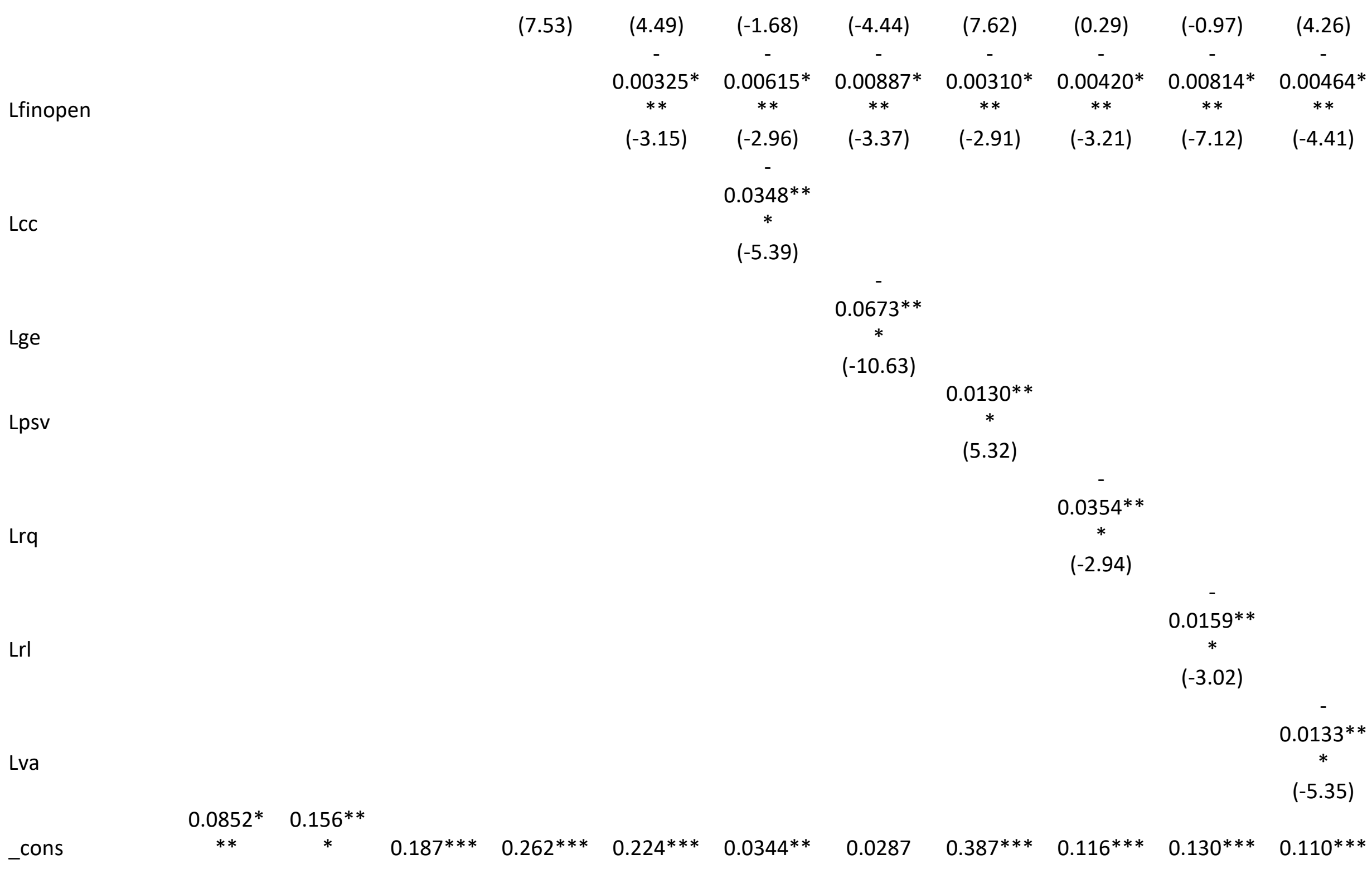


INTERNATIONAL JOURNAL OF ACADEMIC RESEARCH IN BUSINESS AND SOCIAL SCIENCES Vol. 11, No. 18, TiBECVII 2021, 2021, E-ISSN: 2222-6990 @ 2021 HRMARS

\begin{tabular}{|c|c|c|c|c|c|c|c|c|c|c|c|}
\hline & $(5.74)$ & $(5.90)$ & $(12.99)$ & $(17.45)$ & $(9.00)$ & $(2.10)$ & $(0.66)$ & (10.99) & $(3.02)$ & $(4.65)$ & $(4.77)$ \\
\hline Observation & 258 & 258 & 258 & 258 & 258 & 258 & 258 & 258 & 258 & 258 & 258 \\
\hline No of Countries & 43 & 43 & 43 & 43 & 43 & 43 & 43 & 43 & 43 & 43 & 43 \\
\hline $\mathrm{AR}(1)$ & 0.0567 & 0.0569 & 0.0587 & 0.0638 & 0.0615 & 0.0537 & 0.0510 & 0.0637 & 0.0631 & 0.0604 & 0.0659 \\
\hline$A R(2)$ & 0.225 & 0.251 & 0.272 & 0.408 & 0.369 & 0.168 & 0.133 & 0.506 & 0.253 & 0.289 & 0.386 \\
\hline Chi2-Sargan test & $0.000 * *$ & $0.000 * *$ & & & & & & & & & \\
\hline$p$-value & $*$ & $*$ & $0.000 * * *$ & $0.000 * * *$ & $0.000 * * *$ & $0.000 * * *$ & $0.000 * * *$ & $0.000 * * *$ & $0.000 * * *$ & $0.000 * * *$ & $0.000 * * *$ \\
\hline \multicolumn{12}{|l|}{ Chi2-Hansen } \\
\hline test $p$-value & 0.297 & 0.408 & 0.582 & 0.293 & 0.297 & 0.296 & 0.352 & 0.277 & 0.282 & 0.311 & 0.159 \\
\hline \multicolumn{12}{|c|}{ Dependent variable: fertility (Ltfr), two-step system GMM. Figures in parenthesis are t-statistics. Asterisk ( $\left.{ }^{* * *}\right)$ and $(* *)$ denote statistically } \\
\hline \multicolumn{12}{|l|}{ Dependent } \\
\hline \multirow[t]{3}{*}{ Variable } & \multicolumn{11}{|c|}{ Fertility } \\
\hline & & & & & & & & & & & Model \\
\hline & Model 1 & Model 2 & Model 3 & Model 4 & Model 5 & Model 6 & Model 7 & Model 8 & Model 9 & Model 10 & 11 \\
\hline \multirow{4}{*}{ L.Itfr } & $0.920 * *$ & $0.897^{* *}$ & & $0.783 * *$ & & $0.827^{* *}$ & $0.843 * *$ & $0.828 * *$ & & & $0.840 * *$ \\
\hline & $*$ & $*$ & $0.842 * * *$ & $*$ & $0.838 * * *$ & $*$ & $*$ & $*$ & $0.841 * * *$ & $0.837 * * *$ & $*$ \\
\hline & $(154.63)$ & (122.57) & (93.18) & (79.18) & $(64.30)$ & $(65.16)$ & $(55.93)$ & (64.04) & $(63.07)$ & $(56.79)$ & $(63.44)$ \\
\hline & - & - & - & - & - & - & - & - & - & - & - \\
\hline \multirow{3}{*}{ Lliqliab } & $0.0101^{*}$ & $0.0268 *$ & $0.0381 * *$ & $0.0343 *$ & $0.0372 * *$ & $0.0357^{*}$ & $0.0368 *$ & $0.0427^{*}$ & $0.0365 * *$ & $0.0377 * *$ & $0.0347^{*}$ \\
\hline & $* *$ & $* *$ & $*$ & $* *$ & $*$ & $* *$ & $* *$ & $* *$ & $*$ & $*$ & $* *$ \\
\hline & $(-5.38)$ & $(-9.26)$ & $(-13.26)$ & $(-4.92)$ & $(-8.50)$ & $(-7.25)$ & $(-8.47)$ & $(-8.98)$ & $(-8.13)$ & $(-9.04)$ & $(-7.06)$ \\
\hline \multirow{3}{*}{ Ly } & & $0.0167^{*}$ & $0.0298 * *$ & $0.0635^{*}$ & $0.0308 * *$ & $0.0250^{*}$ & $0.0266^{*}$ & $0.0383^{*}$ & $0.0289 * *$ & $0.0289 * *$ & $0.0274^{*}$ \\
\hline & & $* *$ & $*$ & $* *$ & $*$ & $* *$ & $* *$ & $* *$ & $*$ & $*$ & $* *$ \\
\hline & & $(4.48)$ & $(5.25)$ & $(7.83)$ & (4.17) & (3.15) & (2.97) & $(5.41)$ & (3.83) & (3.13) & (3.35) \\
\hline
\end{tabular}


INTERNATIONAL JOURNAL OF ACADEMIC RESEARCH IN BUSINESS AND SOCIAL SCIENCES

Vol. 11, No. 18, TiBECVII 2021, 2021, E-ISSN: 2222-6990 @ 2021 HRMARS

Ltop

$\begin{array}{ccccccccc}0.00963^{*} & 0.0343^{*} & 0.00884 * & 0.0123^{*} & 0.00888 & & 0.00931^{*} & 0.00983 * & 0.0101^{*} \\ * * & * * & * * & * * & * * & -0.00600 & * * & * * & * * \\ (-5.08) & (-8.47) & (-2.96) & (-3.50) & (-2.70) & (-1.94) & (-2.99) & (-2.81) & (-3.00) \\ - & - & - & - & - & - & - & - & \\ 0.0358^{* *} & 0.108^{* *} & 0.0390^{* *} & 0.0515^{*} & 0.0454^{*} & 0.0313^{*} & 0.0412^{* *} & 0.0440^{* *} & \\ * & * & * & * * & * * & * & * & * & -0.0269 \\ (-3.59) & (-8.72) & (-2.82) & (-3.45) & (-2.79) & (-2.14) & (-2.94) & (-3.26) & (-1.33) \\ & 0.0154^{*} & & & & & & & \\ -0.00506 & * & -0.00327 & -0.00699 & -0.00498 & -0.00320 & -0.00505 & -0.00482 & -0.00260 \\ (-0.63) & (2.44) & (-0.31) & (-0.66) & (-0.46) & (-0.30) & (-0.46) & (-0.45) & (-0.25) \\ & 0.0171^{*} & & & & & & & \\ & * * & -0.00200 & -0.00359 & -0.00206 & -0.00228 & -0.00244 & -0.00174 & -0.00185 \\ & (5.66) & (-1.07) & (-1.46) & (-1.10) & -1.05) & (-1.20) & (-0.91) & (-0.99) \\ & & - & - & - & - & - & - & - \\ & & 0.0139 * * & 0.0178 * & 0.0161 * & 0.0131 * & 0.0169 * * & 0.0163 * * & 0.0117 * \\ & & * & * & * * & * * & * & * & * \\ & & (-4.30) & (-4.29) & (-3.23) & (-4.37) & (-3.53) & (-4.21) & (-2.90) \\ & & & 0.0137 & & & & & \end{array}$

Lpsv

$0.0470^{*}$

$* *$

$(-2.80)$

0.0108

(0.88)

0.00982

(0.61) 
INTERNATIONAL JOURNAL OF ACADEMIC RESEARCH IN BUSINESS AND SOCIAL SCIENCES

Vol. 11, No. 18, TiBECVII 2021, 2021, E-ISSN: 2222-6990 @ 2021 HRMARS

Lva

$-0.00814$

$(-0.84)$

$0.0886^{*}$

_cons

$\begin{array}{llll}(8.18) & (0.06) & (4.59) & (3.03)\end{array}$

Observation

252

252

252

42

42

42

252

0.00050

$\operatorname{AR}(1)$

$\begin{array}{lllccc}0.00308 & 0.00266 & 0.00216 & 8 & 0.00230 & 0.0000\end{array}$

$0.264^{* *} \quad 0.200 * * \quad 0.120 * *$

0.136**

$\operatorname{AR}(2)$

$0.753 \quad 0.738$

0.724

0.896

0.742

0.00226

$0.00226 \quad 0.00231$

0.778

$0.000 * * \quad 0.000 * * \quad 0.000 * *$

0.752

$*$

$*$

$0.000 * * * \quad 0.000 * * *$

p-value
Chi2 - Hansen

test $\mathrm{p}$-value

0.210

0.207

0.300

0.207

0.169

$0.128 \quad 0.139$

0.204

0.147

0.141

0.171

Dependent variable: fertility (Ltfr), two-step system GMM. Figures in parenthesis are t-statistics. Asterisk $\left({ }^{* *}\right)$ and $\left({ }^{* *}\right)$ denote statistically significant at the $1 \%$ and $5 \%$ level, respectively. 
Table 6: The effect of financial depth (liquid liability) on fertility ( DEVELOPING)

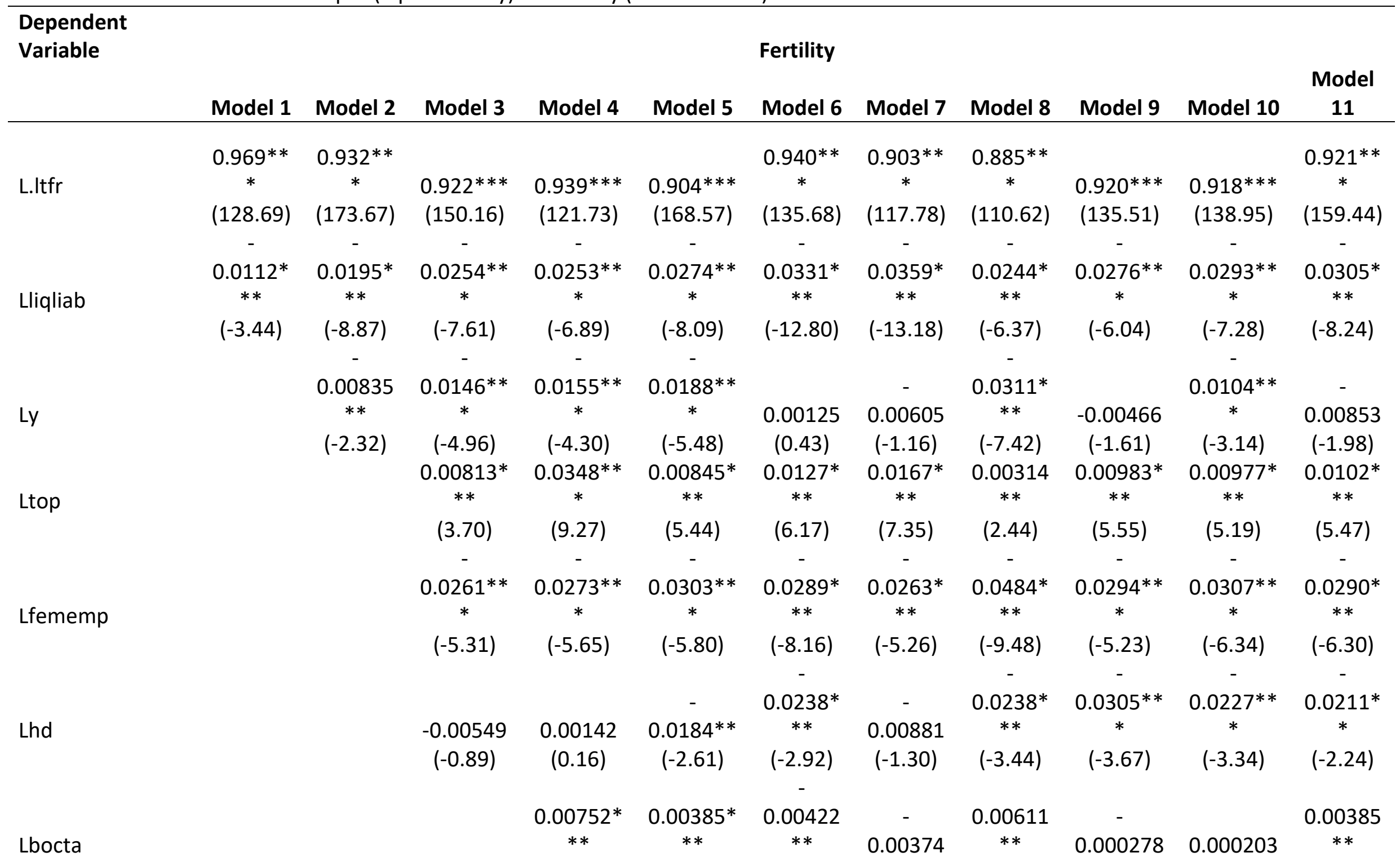


INTERNATIONAL JOURNAL OF ACADEMIC RESEARCH IN BUSINESS AND SOCIAL SCIENCES Vol. 11, No. 18, TiBECVII 2021, 2021, E-ISSN: 2222-6990 @ 2021 HRMARS

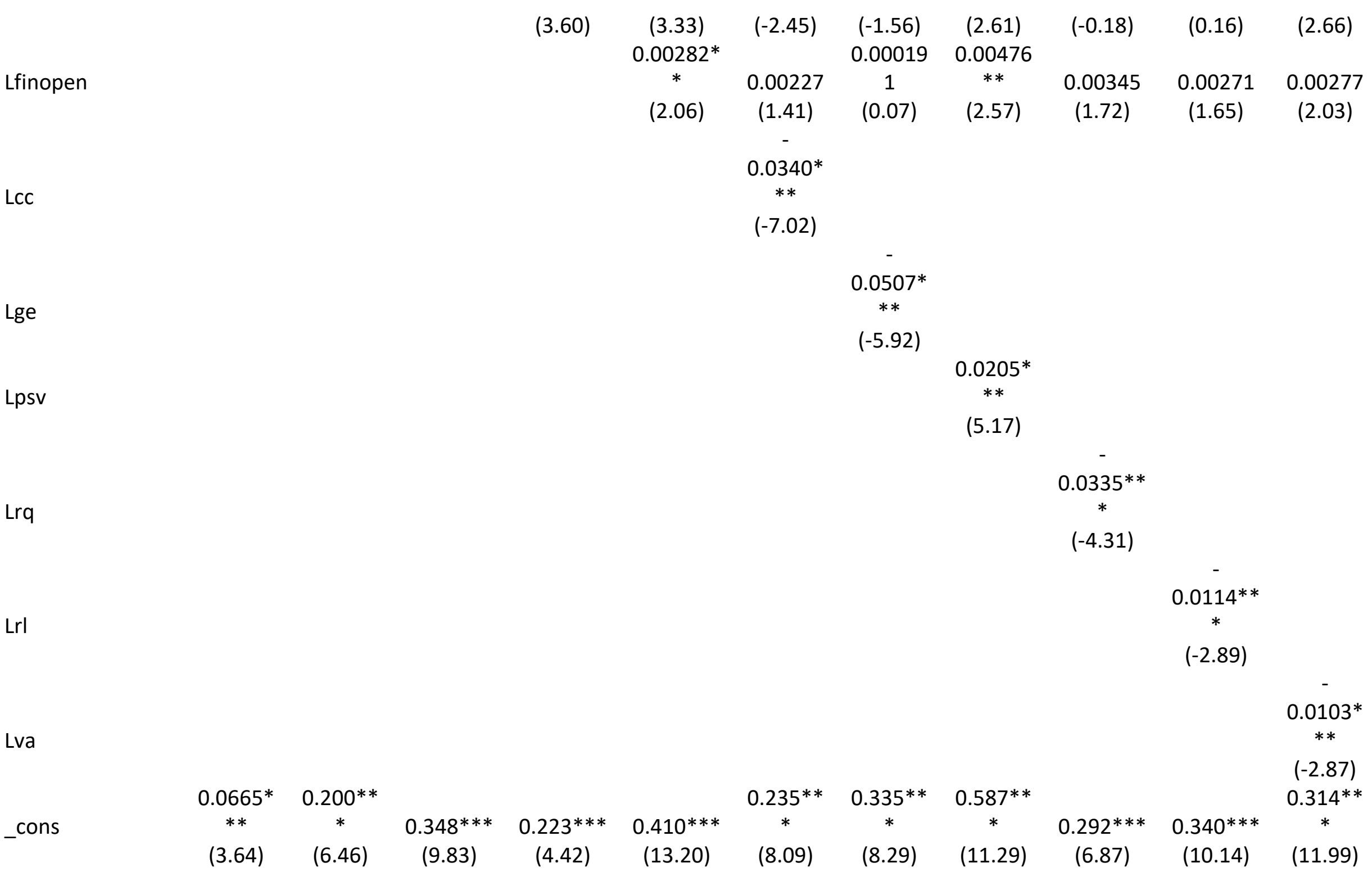


INTERNATIONAL JOURNAL OF ACADEMIC RESEARCH IN BUSINESS AND SOCIAL SCIENCES Vol. 11, No. 18, TiBECVII 2021, 2021, E-ISSN: 2222-6990 @ 2021 HRMARS

\begin{tabular}{|c|c|c|c|c|c|c|c|c|c|c|c|}
\hline Observation & 258 & 258 & 258 & 258 & 258 & 258 & 258 & 258 & 258 & 258 & 258 \\
\hline No of Countries & 43 & 43 & 43 & 43 & 43 & 43 & 43 & 43 & 43 & 43 & 43 \\
\hline$A R(1)$ & 0.0570 & 0.0566 & 0.0574 & 0.0576 & 0.0607 & 0.0537 & 0.0558 & 0.0661 & 0.0614 & 0.0617 & 0.0643 \\
\hline$A R(2)$ & 0.190 & 0.222 & 0.232 & 0.380 & 0.331 & 0.134 & 0.121 & 0.437 & 0.197 & 0.243 & 0.317 \\
\hline Chi2 - Sargan test & $0.000 * *$ & $0.000 * *$ & & & & $0.000 * *$ & $0.000 * *$ & $0.000 * *$ & & & $0.000 * *$ \\
\hline$p$-value & $*$ & $*$ & $0.000 * * *$ & $0.000 * * *$ & $0.000 * * *$ & $*$ & $*$ & $*$ & $0.000 * * *$ & $0.000 * * *$ & $*$ \\
\hline $\begin{array}{l}\text { Chi2 - Hansen } \\
\text { test } p \text {-value }\end{array}$ & 0.256 & 0.410 & 0.699 & 0.273 & 0.526 & 0.348 & 0.309 & 0.575 & 0.515 & 0.433 & 0.385 \\
\hline
\end{tabular}

Dependent variable: fertility (Ltfr), two-step system GMM. Figures in parenthesis are t-statistics. Asterisk $\left({ }^{* * *}\right)$ and $\left({ }^{* *}\right)$ denote statistically significant at the $1 \%$ and $5 \%$ level, respectively. 
INTERNATIONAL JOURNAL OF ACADEMIC RESEARCH IN BUSINESS AND SOCIAL SCIENCES Vol. 11, No. 18, TiBECVII 2021, 2021, E-ISSN: 2222-6990 ๔ 2021 HRMARS

Table 7: The effect of financial access (deposit money) on fertility (DEVELOPED)

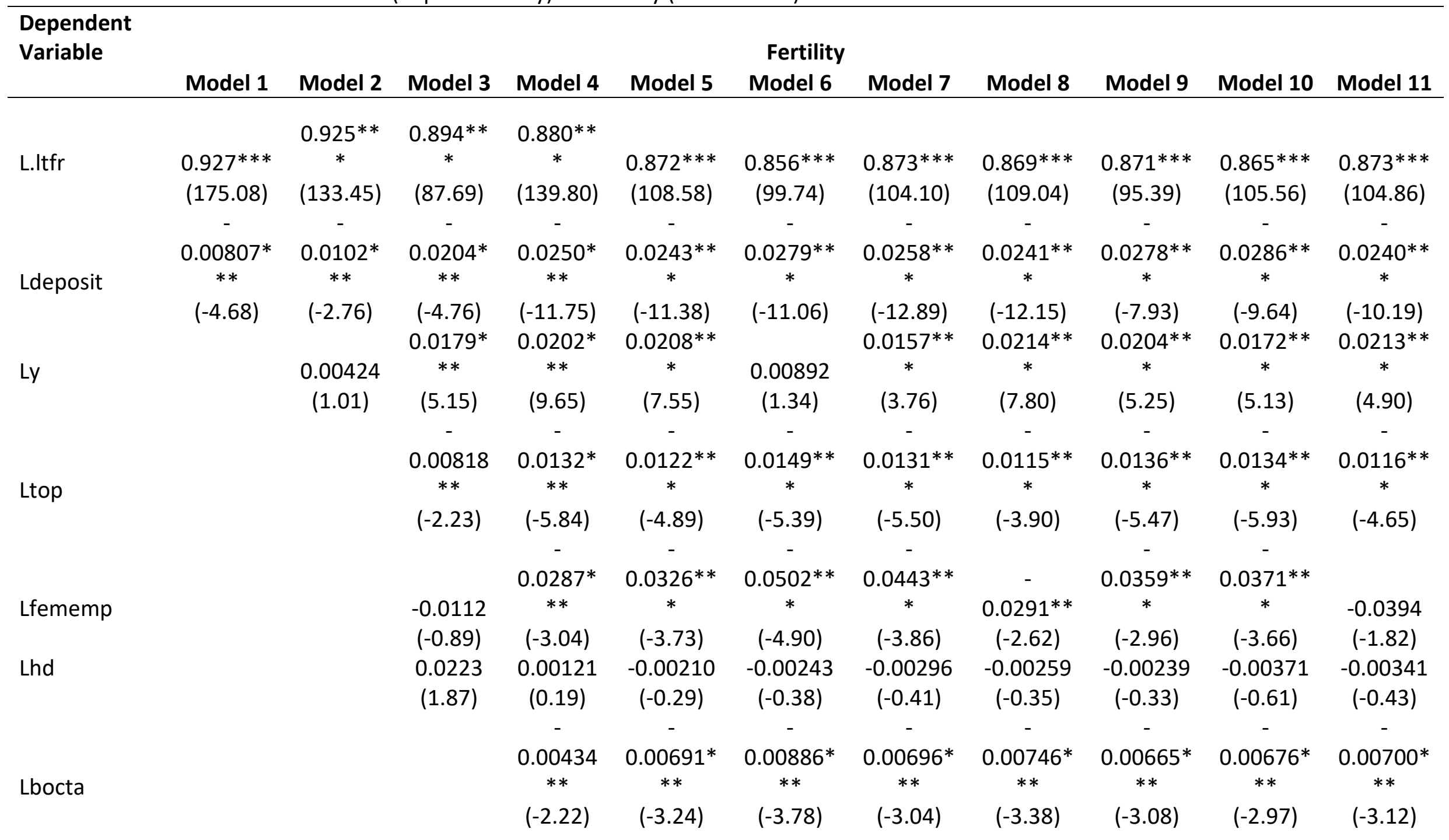


INTERNATIONAL JOURNAL OF ACADEMIC RESEARCH IN BUSINESS AND SOCIAL SCIENCES Vol. 11, No. 18, TiBECVII 2021, 2021, E-ISSN: 2222-6990 @ 2021 HRMARS

\begin{tabular}{|c|c|c|c|c|c|c|c|c|c|c|c|}
\hline & & & & & & & & & & & \\
\hline Lfinopen & & & & & $\begin{array}{c}0.0129 * * \\
* \\
(-4.54)\end{array}$ & $\begin{array}{c}0.0173 * * \\
* \\
(-5.64)\end{array}$ & $\begin{array}{c}0.0154 * * \\
* \\
(-5.60)\end{array}$ & $\begin{array}{c}0.0143 * * \\
* \\
(-4.59)\end{array}$ & $\begin{array}{c}0.0194 * * \\
* \\
(-3.55)\end{array}$ & $\begin{array}{c}0.0179 * * \\
* \\
(-4.16)\end{array}$ & $\begin{array}{c}0.0139 * * \\
* \\
(-4.68)\end{array}$ \\
\hline & & & & & & $0.0352 * *$ & & & & & \\
\hline Lge & & & & & & & $\begin{array}{c}0.0270 \\
(1.88)\end{array}$ & & & & \\
\hline Lrq & & & & & & & & & $\begin{array}{c}0.0226^{* *} \\
(2.14)\end{array}$ & & \\
\hline Lrl & & & & & & & & & & $\begin{array}{c}0.0236 \\
(2.01)\end{array}$ & \\
\hline Lva & & & & & & & & & & & $\begin{array}{c}0.00420 \\
(0.39)\end{array}$ \\
\hline $\begin{array}{l}\text { Observation } \\
\text { No of }\end{array}$ & 252 & 252 & 252 & 252 & 252 & 252 & 252 & 252 & 252 & 252 & 252 \\
\hline Countries & 42 & 42 & 42 & 42 & 42 & 42 & 42 & 42 & 42 & 42 & 42 \\
\hline$A R(1)$ & 0.00318 & 0.00305 & 0.00268 & 0.00285 & 0.00320 & 0.00303 & 0.00313 & 0.00335 & 0.00295 & 0.00304 & 0.00322 \\
\hline $\operatorname{AR}(2)$ & 0.765 & 0.769 & 0.788 & 0.771 & 0.781 & 0.764 & 0.783 & 0.789 & 0.800 & 0.790 & 0.781 \\
\hline Chi2 - Sargan & & $0.000 * *$ & $0.000 * *$ & $0.000 * *$ & & & & & & & \\
\hline $\begin{array}{l}\text { test } p \text {-value } \\
\text { Chi2 - Hansen }\end{array}$ & $0.000 * * *$ & * & * & * & $0.000 * * *$ & $0.000 * * *$ & $0.000 * * *$ & $0.000 * * *$ & $0.000 * * *$ & $0.000 * * *$ & $0.000 * * *$ \\
\hline test $p$-value & 0.199 & 0.166 & 0.335 & 0.165 & 0.156 & 0.102 & 0.126 & 0.144 & 0.108 & 0.110 & 0.124 \\
\hline
\end{tabular}


INTERNATIONAL JOURNAL OF ACADEMIC RESEARCH IN BUSINESS AND SOCIAL SCIENCES

Vol. 11, No. 18, TiBECVII 2021, 2021, E-ISSN: 2222-6990 ๔ 2021 HRMARS

Dependent variable: fertility (Ltfr), two-step system GMM. Figures in parenthesis are t-statistics. Asterisk $\left({ }^{* *}\right)$ and $\left({ }^{* *}\right)$ denote statistically significant at the $1 \%$ and $5 \%$ level, respectively.

Table 8: The effect of financial access (deposit money) on fertility (DEVELOPING)

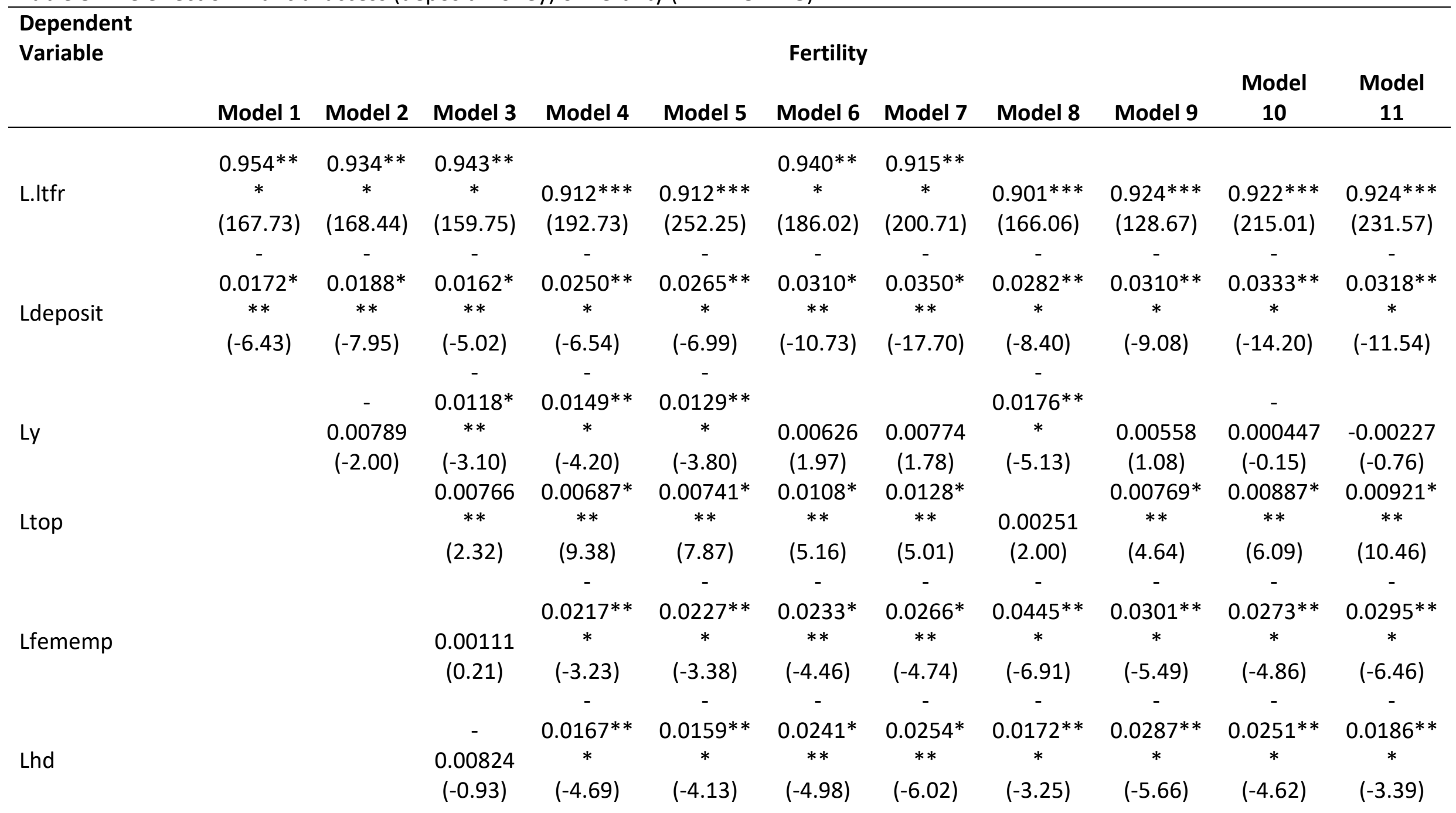


INTERNATIONAL JOURNAL OF ACADEMIC RESEARCH IN BUSINESS AND SOCIAL SCIENCES Vol. 11, No. 18, TiBECVII 2021, 2021, E-ISSN: 2222-6990 @ 2021 HRMARS

\section{Lbocta}

Lfinopen

LCC

Lge

Lpsv

Lrq

Lrl

Lva

$\begin{array}{cccccccc}0.00434 * & 0.00375^{*} & - & 0.00358 & 0.00747^{*} & & - & 0.00443^{*} \\ * * & * * & 0.00185 & * * & * * & 0.000537 & 0.000953 & * * \\ (5.29) & (5.13) & (-0.85) & (-2.04) & (7.97) & (0.60) & (-0.81) & (5.45) \\ & - & - & & & & - & - \\ & 0.00251^{*} & 0.00344 & - & & - & 0.00447^{*} & 0.00210^{*} \\ & * & * * & 0.00363 & -0.00169 & 0.000127 & * * & * \\ & (-2.47) & (-2.26) & (-1.92) & (-1.57) & (-0.07) & (-2.83) & (-2.04) \\ & & - & & & & & \end{array}$

$* *$

$(-4.74)$

$0.0592^{*}$

$* *$

$(-8.20)$ $0.0136^{* *}$

\section{$*$}

(5.89)
$0.0431^{* *}$

$*$

$(-3.47)$
$0.0115^{* *}$

$(-2.30)$
0.00961*

$(-4.15)$ 
INTERNATIONAL JOURNAL OF ACADEMIC RESEARCH IN BUSINESS AND SOCIAL SCIENCES Vol. 11, No. 18, TiBECVII 2021, 2021, E-ISSN: 2222-6990 ๔ 2021 HRMARS

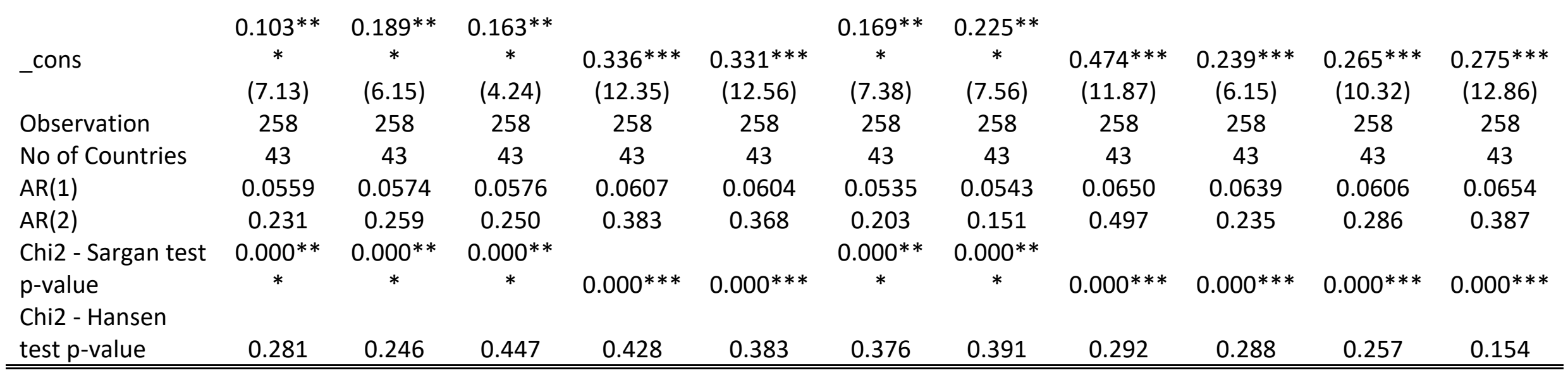

Dependent variable: fertility (Ltfr), two-step system GMM. Figures in parenthesis are t-statistics. Asterisk $\left({ }^{* * *}\right)$ and $\left({ }^{* *}\right)$ denote statistically significant at the $1 \%$ and $5 \%$ level, respectively. 


\section{Conclusions and Implication}

In general, this study indicated that the financial development (measured by private credit, liquid liabilities, and deposit money) was negatively and significantly related to fertility for both developed and developing countries. The real GDP per capita showed positive and negative relationship to fertility choices in developed and developing countries respectively. Meanwhile, female employment, banking efficiencies and financial openness have inverse relationship with fertility in both developed and developing countries. The trade openness affect negatively and positively to fertility in developed and developing countries respectively. However, the result suggested a negative association between human development and fertility in developed countries but insignificant in developing countries. In our analysis, we also found that the empirical estimation of governance factors showed a significant relationship in the fertility decision among parents in both developed and developing countries. More specifically, good governance can increase fertility in developed countries, while good governance discouraged parents to have more children. Perhaps, further research using different tools and methods can be done to explain the variable in more details about how the policymakers play as a crucial role in mitigating the effect of declining fertility worldwide.

In accordance to the objectives of this study, several policy implications emerge from the analysis. Nations, financial sector and economies should take pro-active steps in handling the financial development, socio-economic as well as governance variables. This is to mitigate the issues of reducing fertility due to education attainment, empowerment and changing role of women in workplace, government policies regarding the number of children in certain countries. As proved by this study, there are important linkages between them. Further, the increasing of household debts due to fertility issues should also be highlighted to the policymakers. The effect of decreasing fertility to the financial stability should also not to be overlooked, as it imposes a threat to our financial market in future decades when this generation (children) become adult since they are the highest taxpayers contributors to the government and depositors to the banks.

Generally, overpopulation has delayed the benefits of economic development such as high standard of living and economic welfare. Therefore, low fertility is necessary for economic welfare as it will raise quality of life, allowing for quality of children over quantity of children. This is necessary for the modern era of industrialization as more human capital is required. Parents should be prepared for more investment on human capital and choose the quality of children rather than quantity of children as it increases labour productivity.

Furthermore, an altered age structure will have consequences for the demand for financial services encountered by banks. With the baby boomer generation reaching retirement age and selling off their assets, banks can potentially cushion an eventual asset price meltdown. Hence, there are major challenges and opportunities and thereby bank can contribute to creating financial stability in their role as intermediaries to making the transition a smooth one. Since there will be relatively few individuals working and paying taxes in the future, it will be of benefit to society if individuals entering retirement do so with the funds necessary to live through it, without needing to social welfare institutions. With the world population growing older, leading to an increased level of accumulated wealth, the consumer demand encountered by banks is shifting from credit product to savings products. In particular, asset 
accumulation in anticipation of retirement is of increasing proportion of the population nearing retirement. Given the growing competition in the banking sector and in light of the demographic challenges this sector faces, banks have been forced by creating an innovation environment.

\section{References}

Abid, A., \& Shafiai, M. H. (2018). The determinants of household financial vulnerability in Malaysia and its effect on low-income groups. Journal of Emerging Economies and Islamic Research, 6(1), 32-43.

Adams, C. A., \& Harte, G. (1998). The changing portrayal of the employment of women in British banks'and retail companies' corporate annual reports. Accounting, Organizations and Society, 23(8), 781-812.

Adserà, A. (2004). Changing fertility rates in developed countries: The impact of labor market institutions. Journal of Population Economics, 17(1), 17-43. doi:10.1007/s00148-0030166-x

Khan, A. H. H., Abdullah, H., \& Samsudin, S. (2016). Modelling the determinants of Malaysian household debt. International Journal of Economics and Financial Issues, 6(4), 14681473.

Almasi-Hashiani, A., Sepidarkish, M., Vesali, S., \& Omani-Samani, R. (2016). The correlation of human development index on fertility and mortality rate: A global ecological study. International Journal of Pediatrics, 4(36), 4071-4080. doi:10.22038/ijp.2016.7680

Anderloni, L., Bacchiocchi, E., \& Vandone, D. (2012). Household financial vulnerability: An empirical analysis. Research in Economics, 66(3), 284-296.

Arellano, M., \& Bover, O. (1995). Another look at the instrumental variable estimation of error-component models. Journal of Econometrics, 68, 29-52.

Barro, R. J., \& Becker, G. S. (1989). Fertility choice in a model of economic growth. Econometrica, 57(2), 481-501.

Basso, A., Bodenhorn, H., \& Cuberes, D. (2014). Fertility and financial development: Evidence from U.S. counties in the 19th Century. NBER Working Paper, No. 20491, Cambridge.

Becker, G. S. (1960a). An economic analysis of fertility (Vol. Demographi). Columbia University Press. Retrieved from http://www.nber.org/books/univ60-2

Becker, G. S. (1960b). An economic analysis of fertility. Priceton: Princeton University Press.

Becker, G. S. (1965). A Theory of the Allocation of Time. The Economic Journal, 75(299), 493517.

Becker, G. S., \& Barro, R. J. (1988). A reformulation of the economic theory of fertility. Quarterly Journal of Economics, 53, 1-25.

Becker, G. S., Murphy, K. M., \& Tamura, R. (1990). Human capital , fertility , and economic growth. Journal of Political Economy, 98(5 (Part II)), S12-37.

Beecham, J. (2006). Why costs vary in children's care services. Journal of Children's Services, $1(3), 50-62$.

Bloom, D. E., Canning, D., Fink, G., \& Finlay, J. E. (2009). Fertility, female labor force participation, and the demographic dividend. Journal of Economic Growth, 14(2), 79101. doi:10.1007/s10887-009-9039-9

Bloom, D. E., Canning, D., Hu, L., Liu, Y., Mahal, A., \& Yip, W. (2010). The contribution of population health and demographic change to economic growth in China and India. Journal of Comparative Economics, 38(1), 17-33. doi:10.1016/j.jce.2009.11.002

Blundell, R. W., \& Bond, S. R. (1998). Initial conditions and moment restrictions in dynamic 
panel data models. Journal of Econometric, 87, 115-143.

Bond, S., Hoeffler, A., \& Temple, J. (2001). GMM estimation of empirical growth models. Oxford University, Mimeo.

Caldwell, J. C. (1976). Toward a restatement of demographic transition theory. Population and Development Review, 2(3/4), 321-366.

Chandani, A., Mehta, M., \& Neeraja, B. (2014). Women CEOs and financial performance of banks: An empirical research of Indian private sector banks. Management, 19(1), 231246. Retrieved from http://www.scopus.com/inward/record.url?eid=2-s2.084904039603\&partnerID=40\&md5=9461ddd4e97c0b8e99903209fc013120

Cigno, A., \& Rosati, F. C. (1992). The effects of financial markets and social security on saving and fertility behaviour in Italy. Journal of Population Economicsconomics, 5(4), 319-341. Retrieved from http://www.ncbi.nlm.nih.gov/pubmed/12285683

Cigno, A., \& Rosati, F. C. (1997). Rise and fall of the Japanese saving rate : The role of social security and intra-family transfers. Japan and the World Economy, 9, 81-92.

Cihak, M., Demirguc-Kunt, A., Feyen, E., \& Levine, R. (2012). Benchmarking financial systems around the world. Policy Research Working Paper, No. WPS 6175, The World Bank Group.

Daley, D. M. (1986). Humanistic management and organizational success: The effect of job and work environment characteristics on organizational effectiveness, public responsiveness, and job satisfaction. Public Personnel Management, 15(2), 131-142.

Demirgüç-kunt, A., \& Levine, R. (2008). Finance, financial sector policies, and long-run growth. Policy Research Working Paper, No. 4469, Finance and Private Sector Team, Development Research Group, The World Bank, Washington, USA.

Easterlin, R. (1975). An economic framework for fertility analysis. Studies in Family Planning, 7, 54-63.

Eltigani, E. E. (2005). Fertility transition in Arab countries: A re-evaluation. Journal of Population Research, 22(2), 163-183.

Filoso, V., \& Papagni, E. (2011). Fertility choice and financial development (No. 02/2011). Economics and Econometrics Research Institute, Belgium.

Filoso, V., \& Papagni, E. (2015). Fertility choice and financial development. European Journal of Political Economy, 37, 160-177. doi:10.1016/j.ejpoleco.2014.11.004

FSB. (2016). Global shadow banking monitoring report 2016. Financial Stability Board, Basel, Switzerland. Retrieved from http://www.fsb.org/wp-content/uploads/global-shadowbanking-monitoring-report-2016.pdf

Gallin, J. (2013). Shadow banking and the funding of the nonfinancial sector. Finance and Economic Discussion Series, Divisions of Research \& Statistics and Monetary Affairs, Federal Resercve Board, Washington, D.C.

Galor, O., \& Mountford, A. (2008). Trading population for productivity: Theory and evidence. Review of Economic Studies, 85(4), 1143-1179.

Habibullah, M. S., Farzaneh, N., \& Din, H. B. (2016). Declining fertility and financial development in high income and low-income countries. International Journal of Applied Business and Economic Research, 14(1), 277-290.

Hafner, K. A., \& Mayer-Foulkes, D. (2013). Fertility, economic growth, and human development causal determinants of the developed lifestyle. Journal of Macroeconomics, 38, 107-120. doi:http://dx.doi.org/10.1016/j.jmacro.2013.04.001

Harvey, C. R. (2009). Financial openness and productivity. NBER Working Paper Series, No. 14843.

Hermeto, A. M., \& Caetano, A. J. (2009). Socioeconomics status, family structure and child 
outcomes in Brazil: Health in the childhood. International Journal of Social Economics, 36(10), 979-995.

Huang, S., Chen, Z., Liu, H., \& Zhou, L. (2017). Job satisfaction and turnover intention in China: The moderating effects of job alternatives and policy support. Chinese Management Studies, 11(4), 689-706. doi:10.1108/CMS-12-2016-0263

Kampen, J. K., De Walle, S. V., \& Bouckaert, G. (2006). Assessing the relation between satisfaction with public service delivery and trust in government. The impact of the predisposition of citizens towards government on evaluations of its performance. Public Performance and Management Review, 29(4), 387-404.

Kim, J., Engelhardt, H., Prskawetz, A., \& Aassve, A. (2009). Does fertility decrease household consumption? An analysis of poverty dynamics and fertility in Indonesia. Demographic Research, 20(26), 623-656. doi:10.4054/DemRes.2009.20.26

Konno, S., Teramoto, A., \& Mera, Y. (2011). Compiling statistics of shadow banking. IFC Bulletin, 36, 76-88.

Lee, D.-J., Sirgy, M. J., Singhapakdi, A., \& Lucianetti, L. (2018). The effect of explicit and implicit ethics institutionalization on employee life satisfaction and happiness: The mediating effects of employee experience in work life and moderating effects of work-family life conflict. Journal of Business Ethics, 147(4), 855-874.

Lehr, C. S. (1999). Banking on fewer children : Financial intermediation, fertility and economic development. Journal of Population Economics, 12, 567-590.

Leibenstein, H. (1957). Economic backwardness and economic growth. John Wiley \& Sons Inc: New York.

Liu, S., \& Hu, A. (2013). Demographic change and economic growth: Theory and evidence from China. Economic Modelling, 35, 71-77. doi:10.1016/j.econmod.2013.06.041

Liu, W. C., \& Hsu, C. M. (2006). The role of financial development in economic growth: The experiences of Taiwan, Korea, and Japan. Journal of Asian Economics, 17(4), 667-690. doi:10.1016/j.asieco.2006.06.007

Modigliani, F., \& Brumberg, R. (1954). Utility analysis and the consumption function: An interpretation of cross-section data. In K. K. Kurihara (Ed.), Post-Keynesian Economics. Rutgers University Press, New Brunswick. doi:10.4324/9781315016849

Narayan, P. K. (2006). Determinants of female fertility in Taiwan, 1966-2001: Empirical evidence from cointegration and variance decomposition analysis. Asian Economic Journal, 20(4), 393-407. doi:10.1111/j.1467-8381.2006.00241.x

Neher, P. A. (1971). Peasants, procreation and pensions. American Economic Review, 61(3), 380-389.

Rego, A., Ribeiro, N., Pina e Cunha, M., \& Jesuino, J. C. (2011). How happiness mediates the organizational virtuousness and affective commitment relationship. Journal of Business Research, 64(5), 524-532.

Robinson, W. C., \& Horlacher, D. (1971). Population growth and economic welfare. Population Council, New York.

Ryabov, I. (2015). On the relationship between development and fertility: The case of the United States. Comparative Population Studies, 40(4), 465-488. doi:10.12765/CPoS2015-13en

Schultz, T. W. (1973). The value of children: As economic perspective. Journal of Political Economy, 81(2), S2-13 (Part II).

Tabbarah, R. B. (1971). Toward a theory of demographic development. Economic Development and Cultural Change, 19(2), 257-276. 
Varvarigos, D., \& Arsenis, P. (2015). Corruption, fertility, and human capital. Journal of Economic Behavior \& Organization, 109, 145-162. doi:10.1016/j.jebo.2014.11.006

Wang, Q., \& Sun, X. (2016). The role of socio-political and economic factors in fertility decline : A cross-country analysis. World Development, 87, 360-370. doi:10.1016/j.worlddev.2016.07.004

Werding, M. (2014). Children are costly, but raising them may pay. Demographic Research, 30(8), 253-276. doi:10.4054/demres.2014.30.8

Zakaria, M., Janjua, Y. S. F. B. A., \& Shahzad, H. S. J. (2016). Fertility and financial development in South Asia. Social Indicators Research, 127(3), 1-27. 